\title{
Molecular Targets for Components of Essential Oils in the Insect Nervous System-A Review
}

\author{
Milena Jankowska ${ }^{1, *}$ (D), Justyna Rogalska ${ }^{2}$, Joanna Wyszkowska ${ }^{1}$ and Maria Stankiewicz ${ }^{1}$ \\ 1 Department of Biophysics, Faculty of Biology and Environmental Protection, Nicolaus Copernicus \\ University, Toruń, Poland; Lwowska 1,87-100 Toruń, Poland; jwyszk@umk.pl (J.W.); \\ stankiew@umk.pl (M.S.) \\ 2 Department of Animal Physiology, Faculty of Biology and Environmental Protection, \\ Nicolaus Copernicus University, Toruń, Poland; Lwowska 1, 87-100 Toruń, Poland; rogal@umk.pl \\ * Correspondence: mjank@umk.pl; Tel.: +48-56-611-4296
}

Received: 30 November 2017; Accepted: 21 December 2017; Published: 23 December 2017

\begin{abstract}
Essential oils (EOs) are lipophilic secondary metabolites obtained from plants; terpenoids represent the main components of them. A lot of studies showed neurotoxic actions of EOs. In insects, they cause paralysis followed by death. This feature let us consider components of EOs as potential bioinsecticides. The inhibition of acetylcholinesterase (AChE) is the one of the most investigated mechanisms of action in EOs. However, EOs are rather weak inhibitors of AChE. Another proposed mechanism of EO action is a positive allosteric modulation of GABA receptors (GABArs). There are several papers that prove the potentiation of GABA effect on mammalian receptors induced by EOs. In contrast, there is lack of any data concerning the binding of EO components in insects GABArs. In insects, EOs act also via the octopaminergic system. Available data show that EOs can increase the level of both cAMP and calcium in nervous cells. Moreover, some EO components compete with octopamine in binding to its receptor. Electrophysiological experiments performed on Periplaneta americana have shown similarity in the action of EO components and octopamine. This suggests that EOs can modify neuron activity by octopamine receptors. A multitude of potential targets in the insect nervous system makes EO components interesting candidates for bio-insecticides.
\end{abstract}

Keywords: acetylcholinesterase; bioinsecticides; essential oils; GABA receptors; insect nervous system; octopamine receptor

\section{Introduction}

Essential oils (EOs) are natural, complex substances extracted from different plant organs, and terpenoids are the main components of them [1]. People have taken advantage of EOs as well as their particular components for many centuries. Recently, the historical aspects of use of EOs has been described in detail [2,3]. Nowadays, we know more than 3000 kinds of EOs, about 300 of which are currently used. In traditional agriculture, farmers apply EOs to protect stored grain. EOs are widely utilized as insect repellents, mainly against mosquitoes [3-6]. EOs obtained from lemon and eucalyptus are used as the active substances in non-toxic repellent products that are recommended for children. Moreover, several studies demonstrate that EOs do not only repel the insects but also act on them as neurotoxic compounds [6-18].

It has been proved that EOs from 1500 plant species have insecticidal properties and are efficacious regarding both forms of insects-adults and larvae. For example, eugenol is toxic to a number of insect orders: Coleoptera, Hymenoptera, Isoptera; citral to insect species: Ceratitis capitata and Anastrepha fraterculus; geraniol to Aedes aegypti, Aedes albopictus, Anopheles quadrimaculatus, thymol to Culex tritaeniorhynchus, Aedes albopictus and Anopheles subpictus. All of them are also toxic to the cockroach Periplaneta americana [19-28]. Additionally, extensive research has provided evidence that some EO 
components, applied in binary mixture, can exhibit synergistic or antagonistic activity. Such effects suggest diverse mechanisms of action of EO components [29-31].

Eugenol, $\alpha$-terpineol and L-carvol cause hyperactivity in insects at first. Stretching the legs and numbness precede the insect's death [19-28]. These effects demonstrate the neurotoxic activity of EOs and motivate the investigation of their molecular targets in insect organisms. Understanding the spectrum of action of EOs on insect targets could be crucial for the application of EOs in the development of new, natural insecticides. The aim of this article is to present some identified targets for EOs and shed some light on their mode of action.

\section{Essential Oils-Inhibitors of Acetylcholinesterase}

A lot of research demonstrates that EOs inhibit the activity of acetylcholinesterase (AChE) (Figure 1) (e.g., [32]), which is one of the most important enzymes in neuro-neuronal and neuromuscular junctions in both insects and mammals [33-35]. Since the insect AChE differs from the mammalian one by a single residue, known as the insect-specific cysteine residue, AChE can be an insect-selective target for the newly developed insecticides, safe for non-target vertebrates [36-40]. Essential oils are estimated to be a potential source of insecticides due to their ability to modifying the insect AChE activity [41-51].

\section{The control situation}

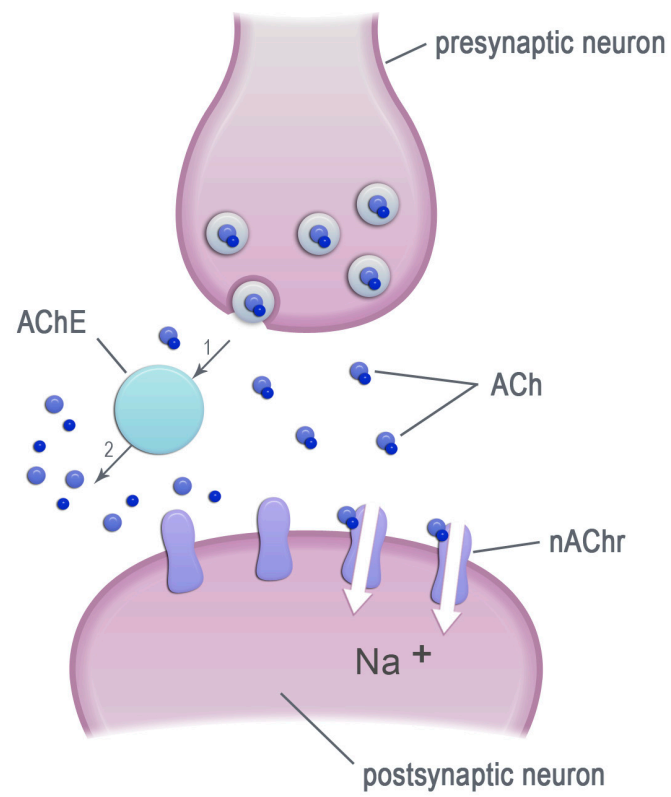

\section{In the presence of EO components}

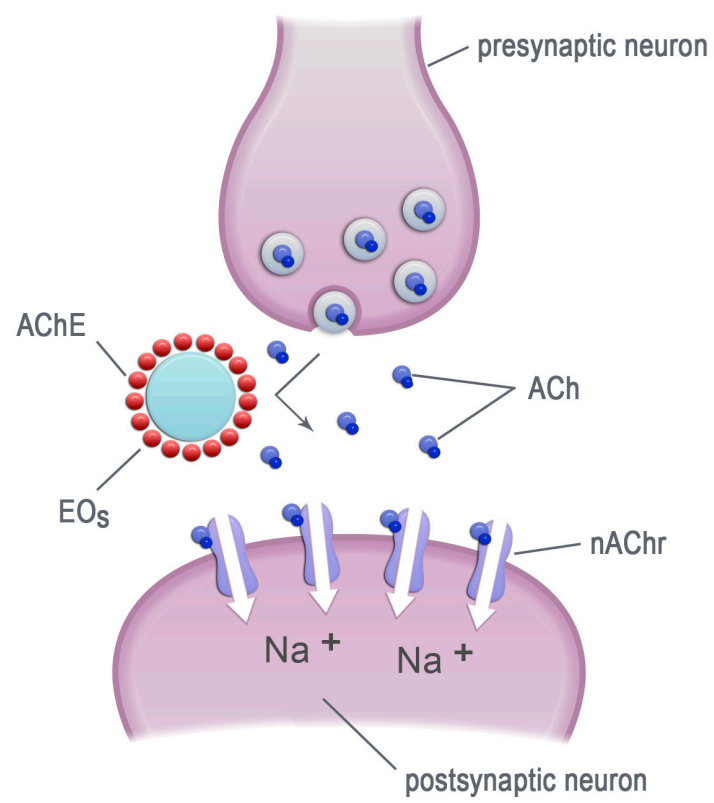

Figure 1. The EO components inhibit the acetylcholinesterase (AChE) activity. ACh-acetylcholinesterase, nAChr-nicotinic acetylcholine receptors, EOs—essential oil components.

It has been demonstrated that EOs from the following plants can inhibit AChE: Chamaemelum nobile, Eriocephalus punctulatus, Ormenis multicaulis, Santolina chamaecyparissus, Cyclotrichium niveum, Thymus praecox subsp. caucasicus var. caucasicus, Echinacea purpurea, Echinacea pallida, Salvia chionantha, Anethum graveolens, Salvia lavendulaefolia [41-45]. Moreover, the properties of the isolated components of EOs have been examined as well (Table 1, Table A1-Appendix A). Forty-eight of 73 examined substances exhibited an anti-AChE activity. However, the experiments were mainly conducted on the isolated $\mathrm{AChE}$ from the electric eel (Electrophorus electricus) and from some species of mammals. Only 28 components were tested on insect AChE and 23 of them inhibited the enzyme. The most efficacious of them were: $\alpha$-pinene and $\beta$-pinene, $\beta$-phellandrene, carvacrol, limonene, menthol, 
menthone, 1,8-cineole, cis-ocimene, niloticin [41,47-54]. Most of the EO components displayed anti-AChE activity in mM concentration. Only one study proved the inhibitory effect of EOs component (carvacrol) on AChE in $\mu \mathrm{M}$ concentration [48].

Table 1. The effects of the essential oil components on the acetylcholinesterase activity in insects.

\begin{tabular}{|c|c|c|c|c|c|}
\hline No. & $\begin{array}{l}\text { Essential Oils } \\
\text { Components }\end{array}$ & AChE Source & $\mathrm{IC}_{50}(\mathrm{mM})$ & $\mathrm{Ki}(\mathrm{mM})$ & Reference \\
\hline \multirow[t]{3}{*}{1} & Anisaldehyde & BxACE-1 from Bursaphelenchus xylophilus & 4.95 & & [46] \\
\hline & & BxACE-2 from Bursaphelenchus xylophilus & 8.53 & & [46] \\
\hline & & BxACE-3 from Bursaphelenchus xylophilus & $>50$ & & [46] \\
\hline 2 & Camphene & Blatella germanica & N.A. & & [47] \\
\hline 3 & Camphor & Blatella germanica & N.A. & & [47] \\
\hline \multirow[t]{3}{*}{4} & 3-Carene & BxACE-1 from Bursaphelenchus xylophilus & 0.37 & & [46] \\
\hline & & BxACE-2 from Bursaphelenchus xylophilus & 8.18 & & [46] \\
\hline & & BxACE-3 from Bursaphelenchus xylophilus & $>50$ & & [46] \\
\hline \multirow[t]{6}{*}{5} & Carvacrol & Musca domestica & 0.0012 & & [48] \\
\hline & & Dermacentor variabilis & 0.0018 & & [48] \\
\hline & & Periplaneta americana & 0.0004 & & [48] \\
\hline & & Aedes aegypti & 0.0012 & & {$[48]$} \\
\hline & & Drosophila suzukii & N.A. & & [49] \\
\hline & & Sitophilus oryzae & & 0.05 & {$[50]$} \\
\hline 6 & $\begin{array}{l}\text { Caryophyllene } \\
\text { (humulene) }\end{array}$ & Blatella germanica & N.A. & & [47] \\
\hline \multirow[t]{2}{*}{7} & 1,8-Cineole & Pediculus humanus capitis & 77 & & [51] \\
\hline & & Sitophilus oryzae & & 0.084 & [50] \\
\hline \multirow[t]{3}{*}{8} & Coniferyl alcohol & BxACE-1 from Bursaphelenchus xylophilus & 1.06 & & [46] \\
\hline & & BxACE-2 from Bursaphelenchus xylophilus & 1.41 & & [46] \\
\hline & & BxACE-3 from Bursaphelenchus xylophilus & 1.13 & & [46] \\
\hline \multirow[t]{2}{*}{9} & Cymene & Sitophilus oryzae & & 0.05 & [50] \\
\hline & & Drosophila suzukii & N.A. & & [49] \\
\hline 10 & $\begin{array}{c}\text { Estragole } \\
\text { (Allylanisole) }\end{array}$ & Blatella germanica & N.A. & & [47] \\
\hline 11 & Eugenol & Sitophilus oryzae & & 0.096 & [50] \\
\hline 12 & Isoeugenol & Sitophilus oryzae & & 0.11 & [50] \\
\hline 13 & Isosafrole & Sitophilus oryzae & & 0.71 & [50] \\
\hline \multirow[t]{2}{*}{14} & Limonene & Sitophilus oryzae & & 0.73 & [50] \\
\hline & & Reticulitermes speratus Kolbe & 0.95 & & [41] \\
\hline 15 & Linalool & Sitophilus oryzae & N.A. & & [50] \\
\hline 16 & Methyleugenol & Sitophilus oryzae & & 0.051 & [50] \\
\hline \multirow[t]{2}{*}{17} & Menthol & Sitophilus oryzae & & 0.048 & [50] \\
\hline & & Drosophila suzukii & N.A. & & [49] \\
\hline \multirow[t]{2}{*}{18} & Menthone & Sitophilus oryzae & & 0.39 & [50] \\
\hline & & Drosophila suzukii & N.A. & & [49] \\
\hline \multirow[t]{3}{*}{19} & Nerolidol & BxACE-1 from Bursaphelenchus xylophilus & 9.98 & & [46] \\
\hline & & BxACE-2 from Bursaphelenchus xylophilus & 15.28 & & [46] \\
\hline & & BxACE-3 from Bursaphelenchus xylophilus & 19.06 & & [46] \\
\hline \multirow[t]{4}{*}{20} & Nootkatone & Musca domestica & $>30$ & & [48] \\
\hline & & Dermacentor variabilis & $>30$ & & [48] \\
\hline & & Periplaneta americana & $>30$ & & [48] \\
\hline & & Aedes aegypti & $>30$ & & [48] \\
\hline \multirow[t]{2}{*}{21} & Ocimene & Japanese termite & 0.96 & & [52] \\
\hline & & Blatella germanica & N.A. & & [47] \\
\hline 22 & Perilla aldehyde & Drosophila suzukii & 3.06 & & [49] \\
\hline
\end{tabular}


Table 1. Cont.

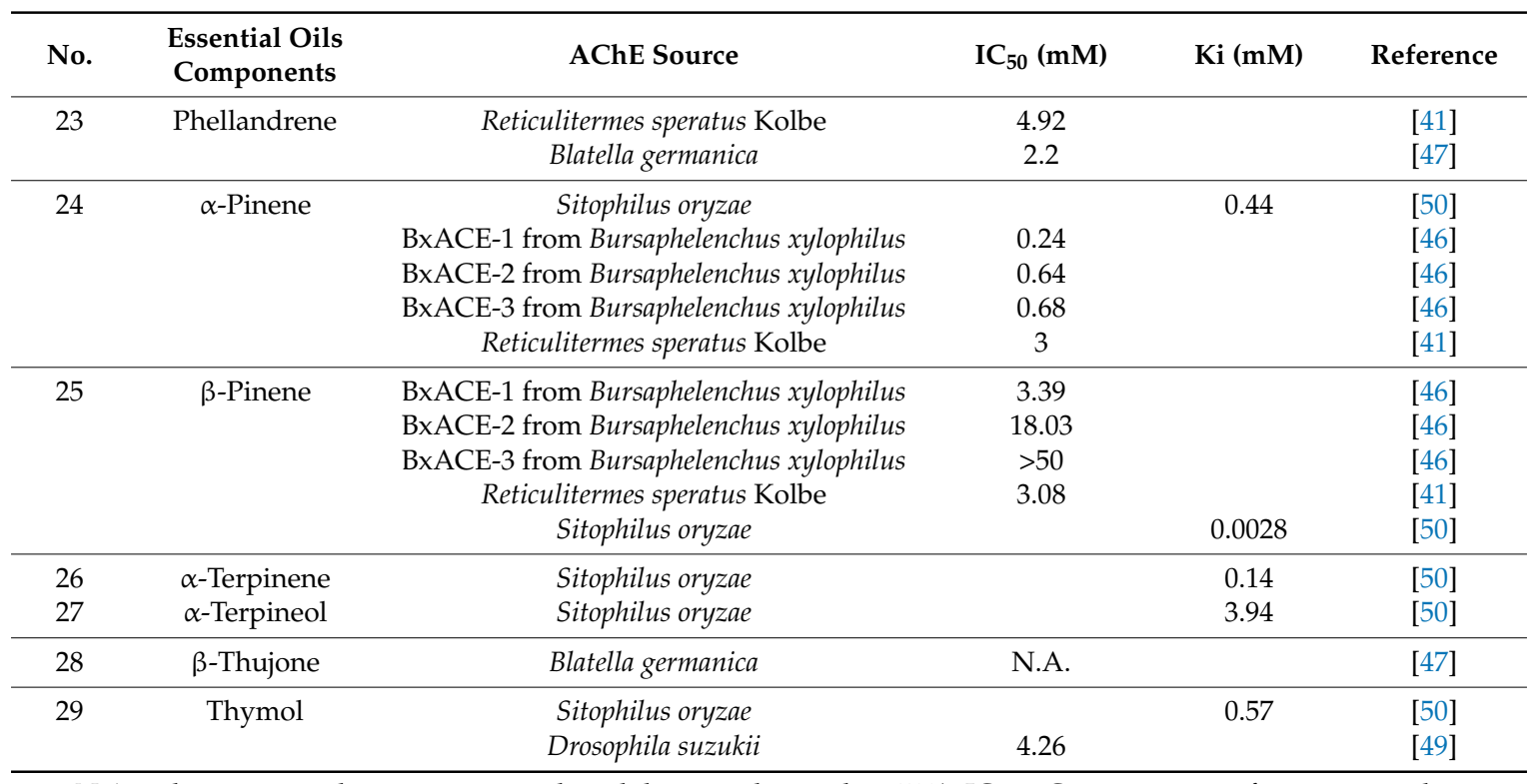

N.A.- - the compound is not active or the inhibition is lower than $50 \% ; \mathrm{IC}_{50}$-Concentration of component that cause $50 \%$ inhibition of enzyme; Ki-inhibitory constant. BxACE-1, BxACE-2 and BxACE-3 are three different acetylcholinesterases found in Bursaphelenchus xylophilus. Values in $\mathrm{mg} / \mathrm{mL}$ were recalculated by the authors of this paper.

To understand the effectiveness of EOs in AChE inhibition we need to consider their exact mode of action and also to recognize the type of inhibition. First of all, knowledge concerning the modification of enzyme kinetics is necessary. In the majority of papers there is no data related to the changes in the AChE kinetics after the EOs' administration. The available research shows that some of the EO constituents function as competitive inhibitors and others as uncompetitive inhibitors (Table 2) [55-60]. It is also difficult to explain the EOs' mode of action because the activity of EOs as complex compounds differs from the activity of their single components. For example, EO from the tea tree (Melaleuca alternifolia) is an uncompetitive inhibitor, while its particular components are competitive inhibitors [57]. Such competitive inhibitors attach to the active sites in AChE and prevent the binding of $\mathrm{ACh}$. It causes the decrease in the binding of the neurotransmitter but the maximal activity of the enzyme remains unchanged. On the other hand, the uncompetitive inhibitors bind to other sites of $\mathrm{AChE}$ and allosterically alter the action of the enzyme. They bind rather to the enzyme-substrate complex than to the enzyme itself and thus prevent product formation. As a result, the maximum activity of the enzyme decreases. Therefore, different inhibitory action of EOs on the $\mathrm{AChE}$ suggests the existence of diverse binding sites in the enzyme molecule.

Table 2. The EO components acting as the competitive and the noncompetitive inhibitors of AChE.

\begin{tabular}{cccc}
\hline Competitive AChE Inhibitors & Reference & Noncompetitive AChE Inhibitors & Reference \\
\hline Pulegon & {$[55]$} & Gossypol & {$[55]$} \\
Citral & {$[55]$} & Carvone & {$[60]$} \\
Linalool & {$[55]$} & Camphor & \\
(-)-Bornyl acetate & {$[55]$} & & \\
1,8-Cineol & {$[55,57,58]$} & & \\
Terpinen-4-ol & {$[57]$} & & \\
Fenchone & {$[60]$} & \\
$\gamma$-Terpinene & {$[60]$} & \\
Menthone & {$[50]$} & & \\
Menthol & {$[50]$} & \\
\hline
\end{tabular}


The AChE enzyme has a deep "active-site gorge" with two target sites: "catalytic" at the bottom and "peripheral" at the entrance [61]. "Dual binding site" inhibitors interact with the AChE at both the catalytic and the peripheral site [62]. Thus, they can act both as competitive and uncompetitive inhibitors. EO components can act as dual inhibitors if they form a blend. López et al. [60] analyzed the kinetics of the inhibition and the spatial size of terpenoids on their binding capability. They conclude that two monoterpenoids can bind to one AChE molecule at a time. The binding of the first EO component favors the attachment of the second one. Moreover, by using a molecular docking, they demonstrated that some components (carvone and fenchone) can bind to several binding sites in the AChE. In contrast, they found only one binding site for terpinene and camphor.

The data described above may suggest a synergistic action of the EO components. In fact, the majority of essential oils exhibit greater activity than their single components. However, we have found only a few papers where the synergistic action of the EO components was estimated using statistical analysis of interaction. Savalev et al. [63] have proposed synergism between 1,8-cineole and $\alpha$-pinene. They obtained similar results for 1,8-cineole and caryophyllene oxide. On the other hand, an antagonistic interaction was found between 1,8-cineole and camphor. Miyazawa et al. [64] also observed antagonism between some EO components. They compared the inhibitory effect of the natural EOs extracted from the plant with the sum of the inhibitory effectiveness of the major single components and with the "artificial" mixture of them. EOs exhibited the highest inhibition (46\%), the sum of the inhibitory action of the EO components was lower $(29.5 \%)$ and the "artificial" mixture of the EO components inhibited the AChE only by $19 \%$. On the other hand, the study by Jukic et al. [65] showed that thyme EO exhibited less activity than its single components. Certainly, the positive or the negative interaction between the $\mathrm{EO}$ components depends on their relative quantity.

The structure-activity relationships for EOs are also unclear. It is difficult to define which chemical type of EO compounds is more active. Lee et al. [50] have suggested that monoterpenoid ketones are more active than alcohols or aldehydes. However, among 6 inactive compounds, two were ketones. In the same study, menthone (ketone) has a lower inhibitory activity than others. Moreover, among active compounds, two were phenolic alcohols. Certainly, it would be necessary to identify other features of chemical structure (e.g., double bond in phenolic ring) to determine the activity of the EO constituents. López et al. [60] have found a correlation between the size of the tested components and their inhibitory activity on the AChE. The substance with higher spatial size exhibited higher activity. Reegan et al. [53] performed a molecular docking of niloticin (large spatial size terpenoid) to the AChE of Aedes aegypti. They showed a high binding affinity of niloticin to the AChE and determined the binding residues as THR'58 and HIS'62. However, Dambolena et al. [66] provided mathematical analysis of factors affecting insecticidal activity of EO components and they discovered that compounds with lower molar volume and fewer rings are more active.

To sum up, the study on EOs as AChE inhibitors showed that monoterpenoids appeared to be weak AChE inhibitors. The inhibition of AChE requires $\mathrm{mM}$ concentrations of EOs [48] while usually neurotoxic symptoms of EOs are visible at their concentrations smaller by 3 orders of magnitude. Additionally, the inhibition of the AChE is always fast reversible [67,68]. Moreover, the chemicals (e.g., carvone) in one study caused the inhibition of AChE but in another study, using the same AChE, no activity was shown, so the results are not reproducible. Thus, AChE inhibition does not seem to be the primary neurotoxic action of EOs, however, some of the large sized EO chemicals can be consider as AChE inhibitors.

\section{Essential Oils-Modifiers of GABA Receptors}

\subsection{Mammalian GABAA Receptors}

Gamma-amminobutyric acid (GABA) is the major inhibitory neurotransmitter in the nervous system and the muscles in both mammals and insects (however in some cases it can play a role of excitatory neurotransmitter). It binds to specific receptors (GABArs) in synaptic or extrasynaptic 
membranes [69-72]. In mammals there are two types of GABA receptors: ionotropic (GABA $\mathrm{A}_{\mathrm{rs}}$ ) and metabotropic $\left(\mathrm{GABA}_{\mathrm{B}} \mathrm{rs}\right)[73,74]$.

Many papers report essential oils action on the GABArs, primarily belonging to the ionotropic receptor group [75]. Studies that proved the influence of essential oils on the GABArs were conducted mainly on mammals. According to a great deal of data, EOs and their components are mostly positive modulators of the $\mathrm{GABA}_{\mathrm{A}}$ receptors (Figure 2). Menthol, thymol and other components increase the $\mathrm{Cl}^{-}$current induced by the GABA neurotransmitter (Table 3) [76-82]. Such a situation occurs in low $(\mu \mathrm{M})$ concentrations of EOs. Additionally, some of the EO constituents induce a weak $\mathrm{Cl}^{-}$ current themselves when applied at a concentration near $1 \mathrm{mM}[75,76,78,80]$. Higher concentrations of previously mentioned EOs do not exert any effects on $\mathrm{GABA}_{\mathrm{A}}$ rs probably because of the desensitization of the receptors [82]. There are also EO components that do not induce any effect on the $\mathrm{GABA}_{\mathrm{A}} \mathrm{rs} \mathrm{Cl}^{-}$ current, for example: camphor, carvone, menthon [76], linalool and $\alpha$-terpineol [83].

The effect of the EO components on the GABA receptors depends on their chemical structure. Different EO stereoisomers vary in their potency to modulate the GABA receptors: (+)-menthol and (+)-borneol have higher activity than (-)-menthol and (-)-borneol [83,84]. The presence of a functional group is important as well. Alcohols have a stronger modulatory effect on the GABA $\mathrm{A}_{\mathrm{rs}}$ (e.g., thymol, menthol, borneol)—than ketones—(linalool, $\alpha$-terpineol) [76,83].

\section{The control situation}

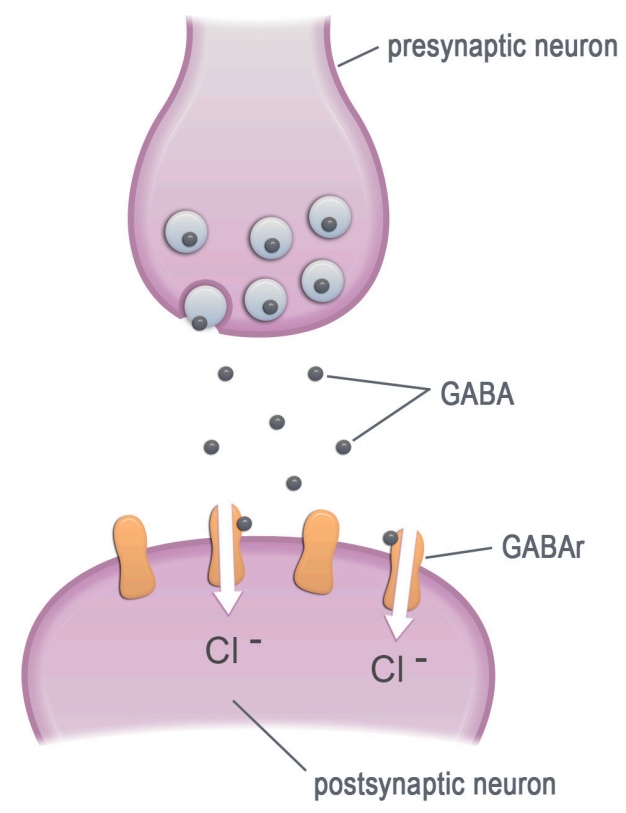

\section{In the presence of EO components}

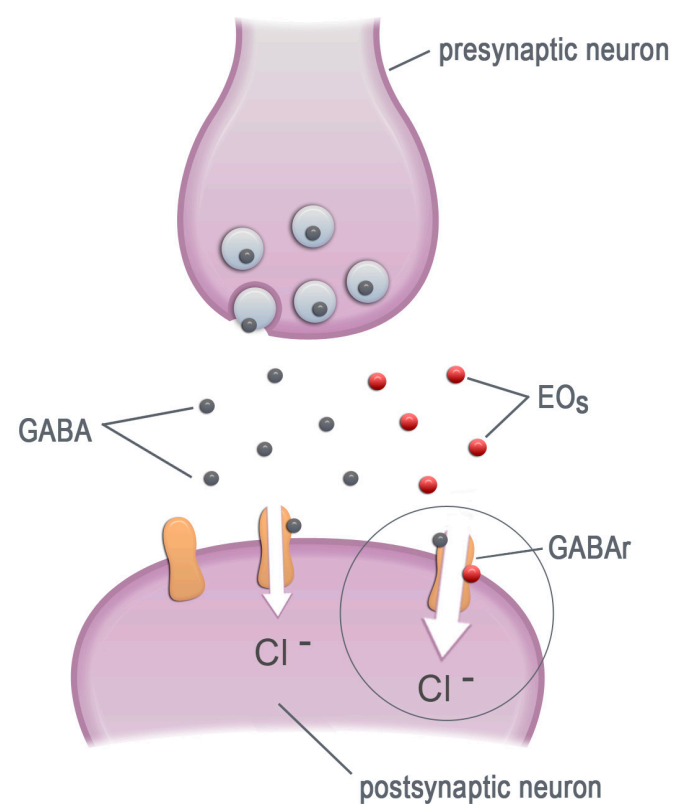

Figure 2. The EO components increase the chloride current by allosteric modulation of the GABA receptors. GABA- $\gamma$-aminobutyric acid, GABAr-GABA receptors, EOs—essential oil components. 
Table 3. The intensification of the GABA-induced $\mathrm{Cl}^{-}$current by EOs.

\begin{tabular}{|c|c|c|c|c|}
\hline EO Components & $\begin{array}{l}\text { Concentration of EOs } \\
\text { Component (mM) }\end{array}$ & $\begin{array}{l}\text { Change of } \\
\text { GABA Current }\end{array}$ & $\begin{array}{c}\text { Type of Receptor or Source of } \\
\text { Receptor }\end{array}$ & Literature \\
\hline (-)-Borneol & 0.3 & $350 \%$ & $\alpha 1 \beta 2 \gamma 2 \mathrm{~s} \mathrm{GABA}_{\mathrm{A}}$ & [76] \\
\hline Camphor & 0.3 & $40 \%$ (inhibition) & $\alpha 1 \beta 2 \gamma 2 \mathrm{~s} \mathrm{GABA}_{\mathrm{A}}$ & [76] \\
\hline Carvone & 0.3 & $115 \%$ & $\alpha 1 \beta 2 \gamma 2 \mathrm{~s} \mathrm{GABA}_{\mathrm{A}}$ & [76] \\
\hline cis-Jasmone & 1 & $250 \%$ & Bovine $\mathrm{GABA}_{\mathrm{A}}$ & [79] \\
\hline Geraniol & 1 & $500 \%$ & $\alpha 1 \beta 1 G A B A_{A}$ & [79] \\
\hline (+)-Isomenthol & 1 & $327 \%$ & $\alpha 1 \beta 2 \gamma 2 \mathrm{~s} \mathrm{GABA}_{\mathrm{A}}$ & [78] \\
\hline (+)-Isopulegol & 0.3 & $380 \%$ & $\alpha 1 \beta 2 \gamma 2 \mathrm{~s} \mathrm{GABA}_{\mathrm{A}}$ & [78] \\
\hline Linalool & 1 & $350 \%$ & $\alpha 1 \beta 1 \mathrm{GABA}_{\mathrm{A}}$ & [79] \\
\hline Nerolidol & 1 & $150 \%$ & $\alpha 1 \beta 1 G A B A_{A}$ & [79] \\
\hline Menthol & 0.32 & $200 \%$ & $\alpha 1 \beta 2 \gamma 2 \mathrm{~s} \mathrm{GABA}_{\mathrm{A}}$ & [78] \\
\hline (+)-Menthol & 0.1 & $596 \%$ & $\alpha 1 \beta 2 \gamma 2 \mathrm{~s} \mathrm{GABA}_{\mathrm{A}}$ & [76] \\
\hline (-)-Menthol & 0.3 & $600 \%$ & $\alpha 1 \beta 2 \gamma 2 \mathrm{~s} \mathrm{GABA}_{\mathrm{A}}$ & [76] \\
\hline (-)-Menthone & 0.3 & $150 \%$ & $\alpha 1 \beta 2 \gamma 2 \mathrm{~s}_{\mathrm{GABA}}$ & [76] \\
\hline Methyleugenol & 0.03 & $280 \%$ & hippocampal neurons & [80] \\
\hline Methyl jasmonate & 1 & $230 \%$ & Bovine $\mathrm{GABA}_{\mathrm{A}}$ & [79] \\
\hline$\alpha$-Terpineol & 1 & $299 \%$ & $\alpha 1 \beta 2 \gamma 2 \mathrm{~s} \mathrm{GABA}_{\mathrm{A}}$ & [78] \\
\hline \multirow[t]{2}{*}{$\alpha / \beta$-Thujone } & 0.3 & $40 \%$ (inhibition) & $\alpha 1 \beta 2 \gamma 2 \mathrm{~s}_{\mathrm{GABA}}$ & [76] \\
\hline & 0.1 & $715 \%$ & $\begin{array}{c}\text { Drosophila melanogaster } \\
\text { homomeric RDLac GABAr }\end{array}$ & [76] \\
\hline \multirow[t]{2}{*}{$\alpha$-Thujone } & 0.00066 & $208 \%$ & Rat GABA & [81] \\
\hline & 0.003 & 70\% (inhibition) & rat dorsal root ganglion neurons & [82] \\
\hline \multirow[t]{2}{*}{ Thymol } & 0.1 & $416 \%$ & $\alpha 1 \beta 3 \gamma 2 \mathrm{~s} \mathrm{GABA}_{\mathrm{A}}$ & [75] \\
\hline & 0.01 & $150 \%$ & $\alpha 1 \beta 1 \gamma 2 \mathrm{~s} \mathrm{GABA}_{\mathrm{A}}$ & [75] \\
\hline
\end{tabular}

Values in $\mathrm{mg} / \mathrm{mL}$ were recalculated by the authors of this paper.

Many studies have been performed to define the binding sites for the EO components in the GABArs $[76,78,85]$. However, such experiments are rather difficult to carry out in natural, neuronal membranes, because EOs are lipophilic substances and they can nonspecifically affect cellular membranes: they can increase the membrane permeability or cause damage [86]. The majority of data concerning EOs binding to the $\mathrm{GABA}_{\mathrm{A}}$ rs was obtained using competitive studies with already known $\mathrm{GABA}_{\mathrm{A}}$ rs ligands. Such experiments can only provide indirect evidences for the existence of binding sites for the EO components in the GABArs and should be complemented by more direct methods. Recent knowledge concerning the EO binding sites in the GABArs is presented below.

Although EOs do not compete with the GABA site antagonists [80], in $\mathrm{mM}$ concentrations EOs can cause weak $\mathrm{Cl}^{-}$currents inhibited by bicuculline (a competitive antagonist of the $\mathrm{GABA}_{\mathrm{A}} \mathrm{rs}$ ) [84].

The EO components do not bind to the benzodiazepine site despite the fact that the action of EOs is similar to the action of the benzodiazepines. Watt et al. [78] and Granger et al. [84] have shown that flumazenil (a benzodiazepine site antagonist) did not eliminate the potentiation of a $\mathrm{Cl}^{-}$current induced by menthol and borneol. However, Sánchez-Borzone et al. [87] have observed that carvone can allosterically modify the flunitrazepam binding to the benzodiazepine site.

Moreover, the EO components do not bind to the picrotoxin site. If they did bind to the picrotoxin site, they would have induced the inhibition of the GABA-induced current-but such an effect was not observed. Additionally, picrotoxin completely inhibits the GABA-induced currents modulated by borneol $[80,84]$. EOs are also not competitive for the radioligand $\left[{ }^{3} \mathrm{H}\right]-\mathrm{TBOB}$ (non-competitive channel blocker), in contrast to all ligands of the picrotoxin site [83].

It was proposed that EOs bind to the GABA $\mathrm{A}$ rs anesthetic site. The EO components (e.g., menthol, borneol or geraniol) are structurally similar to a known ligand of the anesthetic site-propofol. Both propofol and menthol are cyclic molecules containing the hydroxyl group. Borneol and geraniol have a similar structure to propofol as well. Moreover, the action of EOs and propofol is similar-they potentiate the GABA induced $\mathrm{Cl}^{-}$current. Propofol itself (in $\mu \mathrm{M}$ concentration) can also cause currents via the GABA ${ }_{A}$ rs. In contrast, such a current was observed only after much higher $(\mathrm{mM})$ concentrations of menthol. However, menthol competed with propofol and significantly decreased the propofol-induced current [78]. It was proposed that propofol binds to the GABA ${ }_{A}$ rs between $\beta+-\beta-$ 
and $\beta+-\alpha-$ subunits [88]. Additionally, propofol can bind to another $\beta$ subunits combination but only at a $10 \times$ higher concentration [89]. Amino acid residues crucial for the propofol binding are located in positions: $265,236,296,286,444$. These residues are also proposed as amino-acid residues participating in EOs binding [78,88-90].

To summarise, the EO components most probably share a binding site with propofol in the GABArs of mammals. A similar action of these compounds was proved in behavioral experiments. Both EOs and propofol cause sedation of a mouse (Mus musculus) [91] and a silver catfish (Rhamdia quelen) [92].

\subsection{Insect $G A B A$ Receptors}

The insect GABArs are related to vertebrate ionotropic GABArs. Similarly to vertebrates, in the insect nervous system GABArs mainly mediate the inhibitory effect on neurotransmission. However, there are several structural and pharmacological differences between the mammalian and the insect GABArs and thus the insect GABArs can be a very promising target for the development of new insecticides. The insect GABArs display features of both mammalian $\mathrm{GABA}_{\mathrm{A}}$ and $\mathrm{GABA}_{\mathrm{C}}$ receptors. The level of similarity between the insect and the mammalian GABArs is the same as between the insect GABArs and the insect nicotinic receptors. The insect GABArs are similar (85-99\%) in different orders of insects. Three kinds of subunits were identified in the insect GABArs: RDL (resistant to dieldrin), GRD (GABA and glycine-like receptor of Drosophila) and LCCH3 (ligand gated chloride channel homologue 3). Among the insect GABArs subunits LCCH3 is the most similar to the mammalian GABArs - precisely to the $\beta 3$ subunit of the $\mathrm{GABA}_{\mathrm{A}}$ rs. The resemblance in the amino acid sequence between the LCCH3 and the $\mathrm{GABA}_{\mathrm{A}} \beta 3$ subunit amounts to 50\% [93]. However, the presence of the LCCH3 subunit in insects is time- and tissue-limited. Experiments on Drosophila melanogaster showed that LCCH3 is located in cell bodies of the embryonic nerve cord and brain, in neuronal cell bodies surrounding the adult brain and in the olfactory system [94,95]. In contrast to the mammalian $\mathrm{GABA}_{\mathrm{A}} \mathrm{rs}$, the majority of the insect GABArs is insensitive to bicuculline and, differently than the subclass $\mathrm{GABA}_{C} \mathrm{rs}$, they can be allostericaly modified by benzodiazepines and barbiturates [69].

Homomeric GABA receptors composed of the RDL subunits are accepted as a model to study the physiology and pharmacology of the insect GABArs because they are blocked by picrotoxin and they are insensitive to bicuculline [96,97]. The insect GABArs are targets for several chemical insecticides such as dieldrin, fipronil, insane, BIDN (bicyclic dinitrile convulsant). All of them act as antagonists of the GABArs and induce inhibition or overexcitation of the insect nervous system [96-100].

The efficacy of essential oils as insecticides was presented in many publications [101-103] although, the data concerning the effects of EOs on the insect GABArs are very limited. The research on RDL receptors has shown that thymol caused strong potentiation of the $\mathrm{Cl}^{-}$current evoked by GABA. Moreover, thymol alone can induce a small current as well [75]. In addition, thymol, carvacrol and pulegone enhanced the binding of $\left[{ }^{3} \mathrm{H}\right]-\mathrm{TBOB}$ to membranes of the insect's neuronal cells. These monoterpenoids also increased the GABA-induced $\mathrm{Cl}^{-}$uptake in the insect membrane preparations. It was proposed that these EO components are positive allosteric modulators of the insect GABA receptors [83]. It is supported by research by Waliwitiya et al. [104], who observed thymol induced reduction of flight muscle frequency at Phaenicia sericata, which was comparable to GABA effect. Anyway, EO action on the insect GABArs needs further studies.

\section{Essential Oils-Ligands of Octopamine Receptors}

Octopamine (OA) is an invertebrate multifunctional molecule, structurally and physiologically related to vertebrates noradrenaline. It has been found that it can act as a neurotransmitter, as a neurohormone and as a neuromodulator [105-107]. OA is present in the nervous system, neuroendocrine cells and hemolymph [108]. It is involved in the regulation of different forms of insect activity e.g., arousal level. It also plays an essential role in the insect stress response, aggressive behavior and social behavior [109-111]. Modern molecular biology techniques have made it possible to follow in detail the role of OA in the insect organism. OA binds to specific G protein-coupled 
membrane receptors (OAr). The binding of $\mathrm{OA}$ to these receptors leads (via $\mathrm{G}$ protein) to the activation of the enzyme adenylyl cyclase. It transforms ATP to cAMP and causes an increase in the cAMP level, which is a signaling molecule, activating the protein kinase A (PKA). G protein also activates phospholipase C. It leads to the release of calcium from deposits in the endoplasmic reticulum and to the elevation of its intracellular level as well as to the activation of the calcium-dependent protein kinase $\mathrm{C}$ (PKC). Protein kinases phosphorylate a number of enzymes and receptors, which, lead to the modulation of their activity. This results in important changes in cell functions [112].

Three subclasses of OAr have been distinguished-depending on the kind of the G protein-coupled. Moreover, there are two kinds of receptors for which tyramine (TA-a precursor of $\mathrm{OA})$ is a ligand [113]:

- $\alpha$-adrenergic-like-the binding of OA to these receptors increases the level of the intracellular calcium; the secondary effect is an increase of the cAMP level;

- $\quad \beta$-adrenergic-like - the binding of OA to these receptors increases the level of cAMP;

- octopamine/tyramine-the receptors are similar to $\alpha 2$-an adrenergic receptor in mammals. It is sensitive both to OA and TA. TA binding to this receptor causes a decrease in the cAMP level. In contrast, OA binding to the receptor causes an increase in the cAMP level;

- two classes of receptors for TA only: the activation of TyrR II causes an increase of the intracellular calcium level, the activation of TyrR III induces the increase of the calcium level and the decrease of the cAMP level [114-116].

In several papers the authors have demonstrated that EOs act in a similar way to OA (Figure 3). Eugenol, $\alpha$-terpineol and their mixture with cinnamyl alcohol induced an increase in the cAMP level. However, at higher concentrations geraniol and citral decreased the cAMP level. The same EOs reduced the binding of $\left[{ }^{3} \mathrm{H}\right]-\mathrm{OA}$ to receptors [117]. Interestingly, cinnamic alcohol itself increased OA level over 20 times in Blatella germanica [118]. Price and Berry [28] have examined the effect of EOs on the bioelectrical activity of the cockroach (Periplaneta americana) ventral nerve cord and the functions of DUM neurons (dorsal unpaired median neurons) in the terminal abdominal ganglion. Geraniol and citral at low concentrations $(\mu \mathrm{M})$ increased the spontaneous firing rate in the DUM neurons and in the nerve cord. Similar effects were observed after the OA application. However, in higher concentrations $(\mathrm{mM})$ these compounds decreased the activity of the DUM neurons and the nerve cord as well. Eugenol reduced the activity of the DUM neurons and the nerve cord. The depressive effects of high concentrations of EOs may be explained by the destructive influence of EOs on neuronal membranes. A study performed by Enan [117] demonstrated that eugenol, cinnamyl alcohol, 2-phenethyl propionate and trans-anethole exert their toxic effects via OArs. EO components (eugenol, trans-anethole and 2-phenethyl propionate) increased $\mathrm{Ca}^{2+}$ concentrations in HEK-293 cells expressing OArs from cockroach P. americana and D. melanogaster. However, trans-anethole increased and eugenol decreased the cAMP level in these cells. All three of these EO components significantly decreased the binding of $\left[{ }^{3} \mathrm{H}\right]$-yohimbine (ligand of OArs). Kostyukovsky et al. [119] have shown that the EO component SEM-76 caused an increase in the cAMP level, in a similar way to OA. In addition, phentolamine (OArs antagonist) abolished SEM-76-induced changes in the concentration of cAMP.

The effect of EOs was also tested on P. americana tyramine receptors (TArs). Thymol, carvacrol and terpineol inhibited the binding of $\left[{ }^{3} \mathrm{H}\right]-\mathrm{TA}$ to membranes of S2 cells expressing TArs. Moreover, these EOs changed the cAMP level in S2 cells. The effects of EOs were observed in the $\mu \mathrm{M}$ concentrations corresponding to the physiological ligands activity [120].

All the presented data provides convincing arguments that the EO components interact with $\mathrm{OA}$ and TA receptors. They act mainly as agonists of these receptors. Importantly, EOs can be considered as agonists of all types of OArs and TArs. They cause an increase in both the cAMP level and in the intracellular $\mathrm{Ca}^{2+}$ level. Thus, they can induce the activation of kinases PKA and PKC and phosphorylation of many proteins (including ion channels, enzymes and receptors) [121]. The presence of OA in mammals is minor and no OArs was found in mammals (nevertheless, it should be taken into 
account that $\mathrm{OA}$ is prohibited in sport owing to its stimulating properties) [112]. The effects of essential oils components on octopamine receptors specific to insects lead to the conclusion that essential oils represent a very interesting source of molecules for designing the insect pest control.

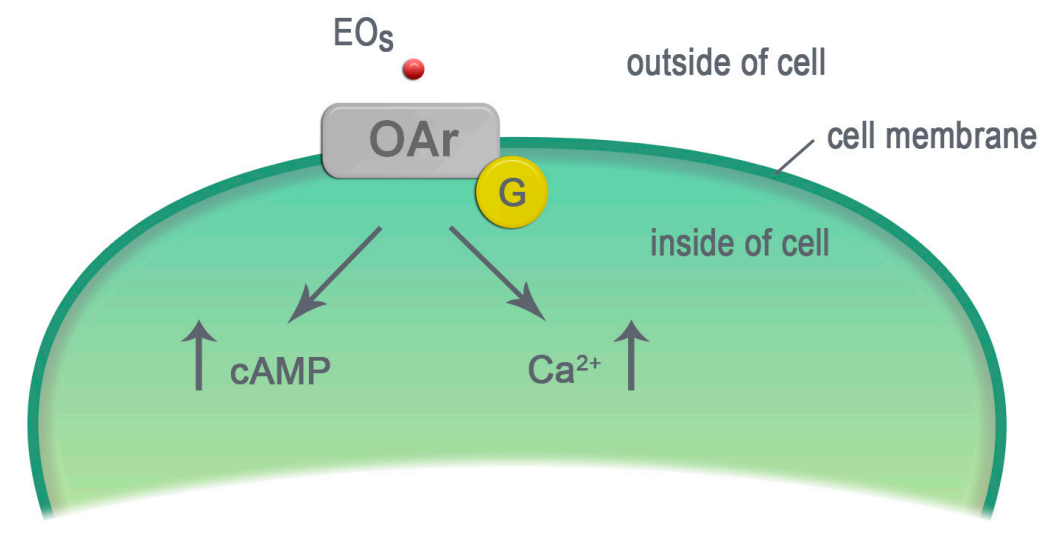

Figure 3. The EO components activate the octopamine receptors. EOs-essential oil components, OAr-octopamine receptor, G-protein G, cAMP—cyclic adenosine monophosphate, $\mathrm{Ca}^{2+}$ —calcium ions, $\uparrow$-increase in the molecule level.

\section{Conclusions}

Studies of neurotoxic effects of essential oils allowed their molecular targets to be determined: acetylcholinesterase enzymes, ionotropic GABA receptors and metabotropic octopamine receptors. The most evident proof concerns the effect of EOs on octopamine receptors, which are specific for invertebrates including insects. This fact strongly motivates future studies on EOs as bioinsecticides.

Acknowledgments: This work was supported by the National Science Centre, Poland under Grant NCN 2014/15/N/NZ9/03868.

Author Contributions: M.J. acquisited the data and wrote the paper. J.W. prepared the tables. J.R. substantively revised the paper. M.S. wrote the paper.

Conflicts of Interest: The authors declare no conflict of interest.

\section{Appendix A}

Table A1. The effects of the essential oil components on the acetylcholinesterase activity in organisms other than insects.

\begin{tabular}{|c|c|c|c|c|c|}
\hline No. & Essential Oil Components & AChE Source & $\mathrm{IC}_{50}(\mathrm{mM})$ & $\mathrm{Ki}(\mathrm{mM})$ & Reference \\
\hline 1 & Anisaldehyde & Electric eel & N.A. & & [122] \\
\hline 2 & Anisole & Human erythrocyte & N.A. & & [123] \\
\hline \multirow[t]{8}{*}{3} & Anethole & Electric eel & N.A. & & [124] \\
\hline & & Electric eel & & & [67] \\
\hline & & Electric eel & 0.88 & & [125] \\
\hline & & Electric eel & 8.9 & & [126] \\
\hline & & Bovine erythrocyte & 0.2 & & [127] \\
\hline & & Electric eel & N.A. & & [122] \\
\hline & & Electric eel & N.A. & & [128] \\
\hline & & Electric eel & 0.87 & & [126] \\
\hline
\end{tabular}


Table A1. Cont.

\begin{tabular}{|c|c|c|c|c|c|}
\hline No. & Essential Oil Components & AChE Source & $\mathrm{IC}_{50}(\mathrm{mM})$ & Ki (mM) & Reference \\
\hline \multirow[t]{6}{*}{4} & Borneol & Bovine erythrocyte & N.A. & & {$[64]$} \\
\hline & & Human erythrocyte & N.A. & & {$[68]$} \\
\hline & & Bovine erythrocyte & N.A. & & [63] \\
\hline & & Electric eel & N.A. & & [122] \\
\hline & & Human erythrocyte & N.A. & & [123] \\
\hline & & Electric eel & N.A. & & [124] \\
\hline \multirow[t]{3}{*}{5} & Bornyl acetate & Electric eel & & 21.3 & [55] \\
\hline & & Human erythrocyte & N.A. & & [68] \\
\hline & & Bovine erythrocyte & N.A. & & [63] \\
\hline 6 & Camphene & Electric eel & N.A. & & [122] \\
\hline \multirow[t]{7}{*}{7} & Camphor & Electric eel & 0.05 & & [67] \\
\hline & & Electric eel & N.A & & [124] \\
\hline & & Electric eel & 11.2 & & {$[60]$} \\
\hline & & Human erythrocyte & N.A. & & [68] \\
\hline & & Bovine erythrocyte & N.A. & & {$[63]$} \\
\hline & & Electric eel & N.A. & & [122] \\
\hline & & Human erythrocyte & N.A. & & [123] \\
\hline 8 & 2-Carene & Bovine erythrocyte & 0.9 & & [58] \\
\hline \multirow[t]{3}{*}{9} & 3-Carene & Human erythrocyte & 0.2 & & [68] \\
\hline & & Bovine erythrocyte & 0.2 & & {$[58]$} \\
\hline & & Electric eel & 0.26 & & [126] \\
\hline \multirow[t]{4}{*}{10} & Carvacrol & Electric eel & 0.41 & & {$[65]$} \\
\hline & & Electric eel & 0.61 & & [126] \\
\hline & & Electric eel & 0.21 & & [122] \\
\hline & & Electric eel & 0.76 & & [128] \\
\hline \multirow[t]{4}{*}{11} & Carvone & Electric eel & 0.3 & & [67] \\
\hline & & Bovine erythrocyte & N.A. & & {$[64]$} \\
\hline & & Electric eel & N.A. & & [122] \\
\hline & & Electric eel & 5.5 & & {$[60]$} \\
\hline \multirow[t]{5}{*}{12} & Caryophyllene (humulene) & Human erythrocyte & N.A. & & [68] \\
\hline & & Bovine erythrocyte & 0.13 & & [68] \\
\hline & & Electric eel & N.A. & & [124] \\
\hline & & Human erythrocyte & N.A. & & [68] \\
\hline & & Electric eel & N.A. & & [129] \\
\hline \multirow[t]{2}{*}{13} & Caryophyllene oxide & Human erythrocyte & N.A. & & [68] \\
\hline & & Bovine erythrocyte & N.A. & & [63] \\
\hline \multirow[t]{11}{*}{14} & 1,8-Cineole & Electric eel & & 0.025 & [55] \\
\hline & & Electric eel & 0.1 & & [124] \\
\hline & & Electric eel & 0.71 & & [126] \\
\hline & & Bovine erythrocyte & 0.26 & & [64] \\
\hline & & Electric eel & 0.6 & & {$[51]$} \\
\hline & & Electric eel & 0.84 & & [122] \\
\hline & & Human erythrocyte & 0.4 & & [68] \\
\hline & & Electric eel & 0.04 & 0.03 & [57] \\
\hline & & Bovine erythrocyte & 0.29 & 0.1 & [58] \\
\hline & & Bovine erythrocyte & 0.39 & & [63] \\
\hline & & Human erythrocyte & 0.67 & & [130] \\
\hline 15 & Cinnamaldehyde & Electric eel & N.A. & & [122] \\
\hline 16 & Cinnamyl alcohol & Electric eel & N.A. & & [122] \\
\hline \multirow[t]{3}{*}{17} & Citral & Electric eel & & 7 & [55] \\
\hline & & Electric eel & N.A. & & [124] \\
\hline & & Electric eel & N.A. & & [122] \\
\hline
\end{tabular}


Table A1. Cont.

\begin{tabular}{|c|c|c|c|c|c|}
\hline No. & Essential Oil Components & AChE Source & $\mathrm{IC}_{50}(\mathrm{mM})$ & $\mathrm{Ki}(\mathrm{mM})$ & Reference \\
\hline 18 & Citronellal & Electric eel & N.A. & & [122] \\
\hline 19 & Citronellol & Electric eel & N.A. & & [122] \\
\hline 20 & Copaene & Human erythrocyte & N.A. & & [68] \\
\hline 21 & Cymene & Bovine erythrocyte & N.A. & & [58] \\
\hline 22 & Elemol & Bovine erythrocyte & 0.16 & & [64] \\
\hline \multirow{4}{*}{23} & Estragole (Allylanisole) & Electric eel & 0.15 & & [67] \\
\hline & & Electric eel & 12.6 & & {$[60]$} \\
\hline & & Electric eel & N.A. & & [124] \\
\hline & & Electric eel & N.A. & & [122] \\
\hline \multirow[t]{3}{*}{24} & Eugenol & Electric eel & 2.9 & & [124] \\
\hline & & Electric eel & N.A. & & [122] \\
\hline & & Human erythrocyte & N.A. & & [123] \\
\hline \multirow[t]{2}{*}{25} & Fenchone & Electric eel & 0.4 & & [67] \\
\hline & & Electric eel & 7 & & {$[60]$} \\
\hline \multirow[t]{3}{*}{26} & Geraniol & Electric eel & 0.1 & & [67] \\
\hline & & Electric eel & 15 & & {$[60]$} \\
\hline & & Electric eel & N.A. & & [122] \\
\hline 27 & Globulol & Human erythrocyte & N.A. & & [68] \\
\hline 28 & Gossypol & Electric eel & 1.5 & & [55] \\
\hline 29 & Guaiol & Human erythrocyte & N.A. & & {$[68]$} \\
\hline 30 & Isoeugenol & Electric eel & N.A. & & [122] \\
\hline \multirow[t]{6}{*}{31} & Limonene & Electric eel & N.A. & & [124] \\
\hline & & Human erythrocyte & N.A. & & [68] \\
\hline & & Electric eel & 1.61 & & [125] \\
\hline & & Electric eel & 4.33 & & [126] \\
\hline & & Electric eel & N.A. & & [122] \\
\hline & & Bovine erythrocyte & N.A. & & [64] \\
\hline \multirow[t]{8}{*}{32} & Linalool & Electric eel & 0.3 & & [67] \\
\hline & & Electric eel & & 5.5 & {$[55]$} \\
\hline & & Electric eel & N.A. & & [124] \\
\hline & & Electric eel & 15.6 & & {$[60]$} \\
\hline & & Electric eel & N.A. & & [122] \\
\hline & & Human erythrocyte & N.A. & & [68] \\
\hline & & Bovine erythrocyte & N.A. & & [63] \\
\hline & & Bovine erythrocyte & N.A. & & [64] \\
\hline \multirow[t]{2}{*}{33} & Linalyl acetate & Bovine erythrocyte & N.A. & & {$[64]$} \\
\hline & & Electric eel & N.A. & & [129] \\
\hline 34 & Manool & Human erythrocyte & N.A. & & {$[68]$} \\
\hline 35 & Methylcinnamate & Electric eel & N.A. & & [122] \\
\hline \multirow[t]{2}{*}{36} & Methyleugenol & Electric eel & N.A. & & [122] \\
\hline & & Electric eel & N.A. & & [124] \\
\hline 37 & Menthofuran & Bovine erythrocyte & N.A. & & [64] \\
\hline 38 & Menthol & Bovine erythrocyte & N.A. & & [64] \\
\hline \multirow[t]{2}{*}{39} & Menthone & Bovine erythrocyte & N.A. & & {$[64]$} \\
\hline & & Electric eel & N.A. & & [122] \\
\hline 40 & Methol & Human erythrocyte & N.A. & & [123] \\
\hline 41 & Methoxycinnamaldehyde & Electric eel & N.A. & & [124] \\
\hline
\end{tabular}


Table A1. Cont.

\begin{tabular}{|c|c|c|c|c|c|}
\hline No. & Essential Oil Components & AChE Source & $\mathrm{IC}_{50}(\mathrm{mM})$ & $\mathrm{Ki}(\mathrm{mM})$ & Reference \\
\hline 42 & Methyl acetate & Bovine erythrocyte & N.A. & & [64] \\
\hline 43 & Myrcene & Electric eel & N.A. & & [122] \\
\hline 44 & Myrtenal & Electric eel & 0.17 & & [122] \\
\hline 45 & Nerol & Electric eel & N.A. & & [122] \\
\hline 46 & Nerolidol & Electric eel & N.A. & & [122] \\
\hline 47 & Neryl acetate & Human erythrocyte & N.A. & & [68] \\
\hline 48 & Phellandrene & Electric eel & 0.88 & & [129] \\
\hline 49 & Phenylethanol & Electric eel & N.A. & & [122] \\
\hline 50 & $\alpha$-Pinene & $\begin{array}{c}\text { Electric eel } \\
\text { Electric eel } \\
\text { Human erythrocyte } \\
\text { Human erythrocyte } \\
\text { Bovine erythrocytes } \\
\text { Electric eel } \\
\text { Bovine erythrocytes }\end{array}$ & $\begin{array}{c}0.16 \\
10.5 \\
0.7 \\
0.63 \\
0.66 \\
\text { N.A. } \\
0.4\end{array}$ & & $\begin{array}{c}{[124]} \\
{[130]} \\
{[68]} \\
{[131]} \\
{[63]} \\
{[122]} \\
{[58]}\end{array}$ \\
\hline 51 & $\beta$-Pinene & $\begin{array}{c}\text { Electric eel } \\
\text { Human erythrocyte } \\
\text { Bovine erythrocyte } \\
\text { Electric eel }\end{array}$ & $\begin{array}{c}\text { N.A. } \\
1.5 \\
1.5 \\
\text { N.A. }\end{array}$ & & $\begin{array}{c}{[124]} \\
{[68]} \\
{[63]} \\
{[122]}\end{array}$ \\
\hline 52 & Piperitenone oxide & Bovine erythrocyte & 0.38 & & [64] \\
\hline 53 & Piperitenone & $\begin{array}{l}\text { Bovine erythrocyte } \\
\text { Bovine erythrocyte }\end{array}$ & $\begin{array}{l}0.72 \\
0.83\end{array}$ & & $\begin{array}{l}{[64]} \\
{[64]}\end{array}$ \\
\hline 54 & Pulegone & $\begin{array}{c}\text { Electric eel } \\
\text { Bovine erythrocyte }\end{array}$ & 0.89 & 0.85 & $\begin{array}{l}{[55]} \\
{[64]}\end{array}$ \\
\hline 55 & Sabinene & $\begin{array}{l}\text { Human erythrocyte } \\
\text { Electric eel }\end{array}$ & $\begin{array}{l}\text { N.A. } \\
1.25\end{array}$ & & $\begin{array}{c}68] \\
{[125]}\end{array}$ \\
\hline 56 & Sclareol & Human erythrocyte & N.A. & & [68] \\
\hline 57 & $\alpha$-Terpinene & Bovine erythrocyte & N.A. & & [58] \\
\hline 58 & $\gamma$-Terpinene & $\begin{array}{c}\text { Electric eel } \\
\text { Electric eel } \\
\text { Electric eel } \\
\text { Bovine erythrocyte }\end{array}$ & $\begin{array}{c}0.2 \\
\text { N.A. } \\
5.8 \\
\text { N.A. }\end{array}$ & & $\begin{array}{c}{[67]} \\
{[124]} \\
{[60]} \\
{[58]}\end{array}$ \\
\hline 59 & $\alpha$-Terpineol & $\begin{array}{c}\text { Electric eel } \\
\text { Human erythrocyte }\end{array}$ & $\begin{array}{l}8.43 \\
\text { N.A. }\end{array}$ & & $\begin{array}{c}{[124]} \\
{[68]}\end{array}$ \\
\hline 60 & Terpinen-4-ol & $\begin{array}{c}\text { Electric eel } \\
\text { Electric eel } \\
\text { Bovine erythrocyte } \\
\text { Electric eel } \\
\text { Electric eel }\end{array}$ & $\begin{array}{l}20.7 \\
10.30 \\
\text { N.A. } \\
\text { N.A. } \\
\text { N.A. }\end{array}$ & $\begin{array}{c}4.7 \\
2\end{array}$ & $\begin{array}{l}{[124]} \\
{[57]} \\
{[58]} \\
{[129]} \\
{[122]}\end{array}$ \\
\hline 61 & Terpinolene & Electric eel & 1.1 & & [129] \\
\hline 62 & $\alpha$-Thujone & $\begin{array}{l}\text { Human erythrocyte } \\
\text { Electric eel }\end{array}$ & $\begin{array}{l}\text { N.A. } \\
\text { N.A. }\end{array}$ & & $\begin{array}{c}{[68]} \\
{[122]}\end{array}$ \\
\hline 63 & Thymohydroquinone & Electric eel & 0.24 & & [65] \\
\hline 64 & Thymol & $\begin{array}{l}\text { Electric eel } \\
\text { Electric eel } \\
\text { Electric eel }\end{array}$ & $\begin{array}{c}4.9 \\
1.39 \\
\text { N.A. }\end{array}$ & & $\begin{array}{c}{[65]} \\
{[126]} \\
{[122]}\end{array}$ \\
\hline
\end{tabular}


Table A1. Cont.

\begin{tabular}{cccccc}
\hline No. & Essential Oil Components & AChE Source & IC $_{\mathbf{5 0}} \mathbf{( m M )}$ & Ki (mM) & Reference \\
\hline 65 & Thymoquinone & Electric eel & 0.85 & {$[65]$} \\
\hline 66 & Viridiflorol & Bovine erythrocyte & 0.11 & {$[64]$} \\
\hline 67 & Verbenone & Electric eel & 2.66 & {$[122]$} \\
& & Electric eel & 0.73 & {$[128]$} \\
\hline
\end{tabular}

N.A.- the compound is not active or the inhibition is lower than $50 \%$; $\mathrm{IC}_{50}$-Concentration of component that cause $50 \%$ inhibition of enzyme; Ki-inhibitory constant. Values in $\mathrm{mg} / \mathrm{mL}$ were recalculated by the authors of this paper.

\section{References}

1. Bassolé, I.H.N.; Juliani, H.R. Essential oils in combination and their antimicrobial properties. Molecules 2012, 17, 3989-4006. [CrossRef] [PubMed]

2. Pavela, R. History, presence and perspective of using plant extracts as commercial botanical insecticides and farm products for protection against insects-A review. Plant Protect. Sci. 2016, 52, 229-241.

3. Pavela, R.; Benelli, G. Ethnobotanical knowledge on botanical repellents employed in the African region against mosquito vectors-A review. Exp. Parasitol. 2016, 167, 103-108. [CrossRef] [PubMed]

4. Mihajilov-Krstev, T.; Jovanović, B.; Jović, J.; Ilić, B.; Miladinović, D.; Matejić, J.; Rajković, J.; Dorđević, L.; Cvetković, V.; Zlatković, B. Antimicrobial, antioxidative, and insect repellent effects of Artemisia absinthium essential oil. Planta Medica 2014, 80, 1698-1705. [CrossRef] [PubMed]

5. Tisgratog, R.; Sanguanpong, U.; Grieco, J.P.; Ngoen-Kluan, R.; Chareonviriyaphap, T. Plants traditionally used as mosquito repellents and the implication for their use in vector control. Acta Trop. 2016, 157, $136-144$. [CrossRef] [PubMed]

6. Price, D.N.; Berry, M.S. Neurophysiological effects of naturally occurring defensive compounds on the freshwater snail Planorbis corneus: Comparison with effects in insects. J. Chem. Ecol. 2008, 34, 994-1004. [CrossRef] [PubMed]

7. Cilek, J.E.; Hallmon, C.F.; Johnson, R. Limited efficacy of commercially formulated essential oils on vegetation against female Aedes albopictus and Culex quinquefasciatus. J. Agric. Urban Entomol. 2010, 27, 54-60. [CrossRef]

8. Liu, Z.L.; Zhao, N.N.; Liu, C.M.; Zhou, L.; Du, S.S. Identification of insecticidal constituents of the essential oil of Curcuma wenyujin rhizomes active against Liposcelis bostrychophila Badonnel. Molecules 2012, 17, 12049-12060. [CrossRef] [PubMed]

9. Liu, X.C.; Li, Y.P.; Li, H.Q.; Deng, Z.W.; Zhou, L.; Liu, Z.L.; Du, S.S. Identification of repellent and insecticidal constituents of the essential oil of Artemisia rupestris L. aerial parts against Liposcelis bostrychophila Badonnel. Molecules 2013, 18, 10733-10746. [PubMed]

10. Liu, X.C.; Zhou, L.G.; Liu, Z.L.; Du, S.S. Identification of insecticidal constituents of the essential oil of Acorus calamus rhizomes against Liposcelis bostrychophila Badonnel. Molecules 2013, 18, 5684-5696. [CrossRef] [PubMed]

11. Du, S.S.; Yang, K.; Wang, C.F. Chemical constituents and activities of the essential oil from Myristica fragrans against cigarette beetle Lasioderma serricorne. Chem. Biodivers. 2014, 11, 1449-1456. [CrossRef] [PubMed]

12. Liu, X.C.; Liang, Y.; Shi, W.P.; Liu, Q.Z.; Zhou, L.; Liu, Z.L. Repellent and insecticidal effects of the essential oil of Kaempferia galanga rhizomes to Liposcelis bostrychophila (Psocoptera: Liposcelidae). J. Econ. Entomol. 2014, 107, 1706-1712. [CrossRef] [PubMed]

13. Wang, Y.; You, C.X.; Wang, C.F.; Yang, K.; Chen, R.; Zhang, W.J.; Du, S.S.; Geng, Z.F.; Deng, Z.W. Chemical constituents and insecticidal activities of the essential oil from Amomum tsaoko against two stored-product insects. J. Oleo Sci. 2014, 63, 1019-1026. [CrossRef] [PubMed]

14. Hu, Z.; Chen, Z.; Yin, Z. In vitro acaricidal activity of 1,8-cineole against Sarcoptes scabiei var. cuniculi and regulating effects on enzyme activity. Parasitol. Res. 2015, 114, 2959-2967. [PubMed]

15. Liu, X.C.; Liu, Z.L. Analysis of the essential oil of Illicium henryi Diels root bark and its insecticidal activity against Liposcelis bostrychophila Badonnel. J. Food Prot. 2015, 78, 772-777. [CrossRef] [PubMed]

16. Wang, Y.; You, C.X.; Yang, K.; Wu, Y.; Chen, R.; Zhang, W.J.; Liu, Z.L.; Du, S.S.; Deng, Z.W.; Geng, Z.F.; et al. Bioactivity of essential oil of Zingiber purpureum Rhizomes and its main compounds against two stored product insects. J. Econ. Entomol. 2015, 108, 925-932. [CrossRef] [PubMed] 
17. Wu, Y.; Zhang, W.J.; Wang, P.J.; Yang, K.; Huang, D.Y.; Wei, J.Y.; Tian, Z.F.; Bai, J.F.; Du, S.S. Contact toxicity and repellency of the essential oil of Liriope muscari (DECN.) Bailey against three insect tobacco storage pests. Molecules 2015, 20, 1676-1685. [CrossRef] [PubMed]

18. Zhang, W.J.; Yang, K.; You, C.X.; Wang, Y.; Wang, C.F.; Wu, Y.; Geng, Z.F.; Su, Y.; Du, S.S.; Deng, Z.W. Bioactivity of essential oil from Artemisia stolonifera (Maxim.) Komar. and its main compounds against two stored-product insects. J. Oleo Sci. 2015, 64, 299-307. [CrossRef] [PubMed]

19. Santos, B.A.; Roman-Campos, D.; Carvalho, M.S.; Miranda, F.M.; Carneiro, D.C.; Cavalcante, P.H.; Cândido, E.A.; Filho, L.X.; Cruz, J.S.; Gondim, A.N. Cardiodepressive effect elicited by the essential oil of Alpinia speciosa is related to L-type $\mathrm{Ca}^{2+}$ current blockade. Phytomedicine 2011, 18, 539-543. [CrossRef] [PubMed]

20. Albuquerque, E.L.D.; Lima, J.K.A.; Souza, F.H.O.; Silva, I.M.; Santos, A.A.; Araújo, A.P.; Blank, A.F.; Lima, R.N.; Alves, P.B.; Bacci, L. Insecticidal and repellence activity of the essential oil of Pogostemon cablin against urban ants species. Acta Trop. 2013, 127, 181-186. [CrossRef] [PubMed]

21. Dutra, K.A.; de Oliveira, J.V.; Navarro, D.M.; Barbosa, D.A.; Santos, J.P. Control of Callosobruchus maculatus (FABR.) (Coleoptera: Chrysomelidae: Bruchinae) in Vigna unguiculata (L.) WALP. with essential oils from four Citrus spp. plants. J. Stored Prod. Res. 2016, 68, 25-32. [CrossRef]

22. Nathan, S.S.; Hisham, A.; Jayakumar, G. Larvicidal and growth inhibition of the malaria vector Anopheles stephensi by triterpenes from Dysoxylum malabaricum and Dysoxylum beddomei. Fitoterapia 2008, 79, 106-111. [CrossRef] [PubMed]

23. Cosimi, S.; Rossi, E.; Cioni, P.L.; Canale, A. Bioactivity and qualitative analysis of some essential oils from Mediterranean plants against stored-product pests: Evaluation of repellency against Sitophilus zeamais Motschulsky, Cryptolestes ferrugineus (Stephens) and Tenebrio molitor (L.). J. Stored Prod. Res. 2009, 45, 125-132. [CrossRef]

24. Reegan, A.D.; Gandhi, M.R.; Paulraj, M.G.; Balakrishna, K.; Ignacimuthu, S. Effect of niloticin, a protolimonoid isolated from Limonia acidissima L. (Rutaceae) on the immature stages of dengue vector Aedes aegypti L. (Diptera: Culicidae). Acta Trop. 2014, 139, 67-76. [CrossRef] [PubMed]

25. Govindarajan, M.; Benelli, G. $\alpha$-Humulene and $\beta$-elemene from Syzygium zeylanicum (Myrtaceae) essential oil: Highly effective and eco-friendly larvicides against Anopheles subpictus, Aedes albopictus, and Culex tritaeniorhynchus (Diptera: Culicidae). Parasitol. Res. 2016, 115, 2771-2778. [CrossRef] [PubMed]

26. Ruiz, M.J.; Juárez, M.L.; Alzogaray, R.A.; Arrighi, F.; Arroyo, L.; Gastaminza, G.; Willink, E.; Bardón, A.V.; Vera, T. Toxic effect of citrus peel constituents on Anastrepha fraterculus Wiedemann and Ceratitis capitata Wiedemann immature stages. J. Agric. Food Chem. 2014, 62, 10084-10091. [CrossRef] [PubMed]

27. Govindarajan, M.; Sivakumar, R.; Rajeswary, M.; Veerakumar, K. Mosquito larvicidal activity of thymol from essential oil of Coleus aromaticus Benth. against Culex tritaeniorhynchus, Aedes albopictus, and Anopheles subpictus (Diptera: Culicidae). Parasitol. Res. 2013, 112, 3713-3721. [CrossRef] [PubMed]

28. Price, D.N.; Berry, M.S. Comparison of effects of octopamine and insecticidal essential oils on activity in the nerve cord, foregut, and dorsal unpaired median neurons of cockroaches. J. Insect Physiol. 2006, 52, 309-319. [CrossRef] [PubMed]

29. Pavela, R. Acute toxicity and synergistic and antagonistic effects of the aromatic compounds of some essential oils against Culex quinquefasciatus Say larvae. Parasitol. Res. 2015, 114, 3835-3853. [CrossRef] [PubMed]

30. Pavela, R. Acute, synergistic and antagonistic effects of some aromatic compounds on the Spodoptera littoralis Boisd. (Lep., Noctuidae) larvae. Ind. Crop. Prod. 2014, 60, 247-258. [CrossRef]

31. Novato, T.P.; Araújo, L.X.; de Monteiro, C.M.; Maturano, R.; Senra Tde, O.; da Silva Matos, R.; Gomes, G.A.; de Carvalho, M.G.; Daemon, E. Evaluation of the combined effect of thymol, carvacrol and (E)-cinnamaldehyde on Amblyomma sculptum (Acari: Ixodidae) and Dermacentor nitens (Acari: Ixodidae) larvae. Vet. Parasitol. 2015, 212, 331-335. [CrossRef] [PubMed]

32. Ingkaninan, K.; Temkitthawon, P.; Chuenchom, K.; Yuyaem, T.; Thongnoi, W. Screening for acetylcholinesterase inhibitory activity in plants used in Thai traditional rejuvenating and neurotonic remedies. J. Ethnopharmacol. 2003, 89, 261-264. [CrossRef] [PubMed]

33. Gnagey, A.L.; Forte, M.; Rosenberry, T.L. Isolation and characterization of acetylcholinesterase from Drosophila. J. Biol. Chem. 1987, 262, 13290-13298. [PubMed]

34. Bourguet, D.; Roig, A.; Toutant, J.P.; Arpagaus, M. Analysis of molecular forms and pharmacological properties of acetylcholinesterase in several mosquito species. Neurochem. Int. 1997, 31, 65-72. [CrossRef] 
35. Marcel, V.; Palacios, L.G.; Pertuy, C.; Masson, P.; Fournier, D. Two invertebrate acetylcholinesterases show activation followed by inhibition with substrate concentration. Biochem. J. 1998, 329, 329-334. [CrossRef] [PubMed]

36. Kim, J.I.; Jung, C.S.; Koh, Y.H.; Lee, S.H. Molecular, biochemical and histochemical characterization of two acetylcholinesterase cDNAs from the German cockroach Blattella germanica. Insect Biochem. Mol. Biol. 2006, 15, 513-522. [CrossRef] [PubMed]

37. Pezzementi, L.; Rowland, M.; Wolfe, M.; Tsigelny, I. Inactivation of an invertebrate acetylcholinesterase by sulfhydryl reagents: The roles of two cysteines in the catalytic gorge of the enzyme. Invertebr. Neurosci. 2006, 6, 47-55. [CrossRef] [PubMed]

38. Pang, Y.P.; Singh, S.K.; Gao, Y.; Lassiter, L.T.; Mishra, R.K.; Zhu, K.Y.; Brimijoin, S. Selective and irreversible inhibitors of aphid acetylcholinesterases: Steps toward human-safe insecticides. PLoS ONE 2009, 4, e4349. [CrossRef] [PubMed]

39. Polsinelli, G.A.; Singh, S.K.; Mishra, R.K.; Suranyi, R.; Ragsdale, D.W.; Pang, Y.P.; Brimijoin, S. Insect-specific irreversible inhibitors of acetylcholinesterase in pests including the bed bug, the eastern yellowjacket, German and American cockroaches, and the confused flour beetle. Chem. Biol. Interact. 2010, 187, 142-147. [CrossRef] [PubMed]

40. Pang, Y.P.; Brimijoin, S.; Ragsdale, D.W.; Zhu, K.Y.; Suranyi, R. Novel and viable acetylcholinesterase target site for developing effective and environmentally safe insecticides. Curr. Drug Targets 2012, 13, 471-482. [CrossRef] [PubMed]

41. Seo, S.M.; Kim, J.; Kang, J.S.; Koh, S.H.; Ahn, Y.J.; Kang, K.S.; Park, I.K. Fumigant toxicity and acetylcholinesterase inhibitory activity of 4 Asteraceae plant essential oils and their constituents against Japanese termite (Reticulitermes speratus Kolbe). Pestic. Biochem. Physiol. 2014, 113, 55-61. [CrossRef] [PubMed]

42. Orhan, I.E.; Şenol, F.S.; Gülpinar, A.R.; Kartal, M.; Sekeroglu, N.; Deveci, M.; Kan, Y.; Sener, B. Acetylcholinesterase inhibitory and antioxidant properties of Cyclotrichium niveum, Thymus praecox subsp. caucasicus var. caucasicus, Echinacea purpurea and E. pallida. Food Chem. Toxicol. 2009, 47, 1304-1310. [CrossRef] [PubMed]

43. Tel, G.; Öztürk, M.; Duru, M.E.; Harmandar, M.; Topçu, G. Chemical composition of the essential oil and hexane extract of Salvia chionantha and their antioxidant and anticholinesterase activities. Food Chem. Toxicol. 2010, 48, 3189-3193. [CrossRef] [PubMed]

44. Orhan, I.E.; Senol, F.S.; Ozturk, N.; Celik, S.A.; Pulur, A.; Kan, Y. Phytochemical contents and enzyme inhibitory and antioxidant properties of Anethum graveolens L. (dill) samples cultivated under organic and conventional agricultural conditions. Food Chem. Toxicol. 2013, 59, 96-103. [CrossRef] [PubMed]

45. Perry, N.S.L.; Houghton, P.J.; Jenner, P.; Keith, A.; Perry, E.K. Salvia lavandulaefolia essential oil inhibits cholinesterase in vivo. Phytomedicine 2002, 9, 48-51. [CrossRef] [PubMed]

46. Kang, J.S.; Kim, E.; Lee, S.H.; Park, I.K. Inhibition of acetylcholinesterases of the pinewood nematode, Bursaphelenchus xylophilus, by phytochemicals from plant essential oils. Pestic. Biochem. Physiol. 2013, 105, 50-56. [CrossRef] [PubMed]

47. Yeom, H.J.; Jung, C.S.; Kang, J.S.; Kim, J.; Lee, J.H.; Kim, D.S.; Kim, H.S.; Park, P.S.; Kang, K.S.; Park, I.K. Insecticidal and acetylcholine esterase inhibition activity of Asteraceae plant essential oils and their constituents against adults of the German cockroach (Blattella germanica). J. Agric. Food Chem. 2015, 63, 2241-2248. [CrossRef] [PubMed]

48. Anderson, J.A.; Coats, J.R. Acetylcholinesterase inhibition by nootkatone and carvacrol in arthropods. Pestic. Biochem. Physiol. 2012, 102, 124-128. [CrossRef]

49. Park, C.G.; Jang, M.; Yoon, K.A.; Kim, J. Insecticidal and acetylcholinesterase inhibitory activities of Lamiaceae plant essential oils and their major components against Drosophila suzukii (Diptera: Drosophilidae). Ind. Crop. Prod. 2016, 89, 507-513. [CrossRef]

50. Lee, S.E.; Lee, B.H.; Choi, W.S.; Park, B.S.; Kim, J.G.; Campbell, B.C. Fumigant toxicity of volatile natural products from Korean spices and medicinal plants towards the rice weevil, Sitophilus oryzae (L). Pest Manag. Sci. 2001, 57, 548-553. [CrossRef] [PubMed]

51. Picollo, M.I.; Toloza, A.C.; Mougabure Cueto, G.; Zygadlo, J.; Zerba, E. Anticholinesterase and pediculicidal activities of monoterpenoids. Fitoterapia 2008, 79, 271-278. [CrossRef] [PubMed] 
52. Park, I.K. Fumigant toxicity of oriental sweetgum (Liquidambar orientalis) and valerian (Valeriana wallichii) essential oils and their components, including their acetylcholinesterase inhibitory activity, against Japanese Termites (Reticulitermes speratus). Molecules 2014, 19, 12547-12558. [CrossRef] [PubMed]

53. Reegan, A.D.; Stalin, A.; Paulraj, M.G.; Balakrishna, K.; Ignacimuthu, S.; Al-Dhabi, N.A. In silico molecular docking of niloticin with acetylcholinesterase 1 (AChE1) of Aedes aegypti L. (Diptera: Culicidae): A promising molecular target. Med. Chem. Res. 2016, 25, 1411-1419. [CrossRef]

54. Abdelgaleil, S.A.M.; Mohamed, M.I.E.; Badawy, M.E.I.; El-Arami, S.A.A. Fumigant and contact toxicities of monoterpenes to Sitophilus oryzae (L.) and Tribolium castaneum (herbst) and their inhibitory effects on acetylcholinesterase activity. J. Chem. Ecol. 2009, 35, 518-525. [CrossRef] [PubMed]

55. Ryan, M.F.; Byrne, O. Plant-insect coevolution and inhibition of acetylcholinesterase. J. Chem. Ecol. 1988, 14, 1965-1975. [CrossRef] [PubMed]

56. Park, T.J.; Seo, H.K.; Kang, B.J.; Kim, K.T. Noncompetitive inhibition by camphor of nicotinic acetylcholine receptors. Biochem. Pharmacol. 2001, 61, 787-793. [CrossRef]

57. Mills, C.; Cleary, B.J.; Gilmer, J.F.; Walsh, J.J. Inhibition of acetylcholinesterase by tea tree oil. J. Pharm. Pharmacol. 2004, 56, 375-379. [CrossRef] [PubMed]

58. Miyazawa, M.; Yamafuji, C. Inhibition of acetylcholinesterase activity by bicyclic monoterpenoids. J. Agric. Food Chem. 2005, 53, 1765-1768. [CrossRef] [PubMed]

59. Miyazawa, M.; Yamafuji, C. Inhibition of acetylcholinesterase activity by tea tree oil and constituent terpenoids. Flavour Fragr. J. 2006, 21, 198-201. [CrossRef]

60. López, M.D.; Campoy, F.J.; Pascual-Villalobos, M.J.; Muñoz-Delgado, E.; Vidal, C.J. Acetylcholinesterase activity of electric eel is increased or decreased by selected monoterpenoids and phenylpropanoids in a concentration-dependent manner. Chem. Biol. Interact. 2015, 229, 36-43. [CrossRef] [PubMed]

61. Taylor, P.; Radić, Z. The cholinesterases: From genes to proteins. Annu. Rev. Pharmacol. Toxicol. 1994, 34, 281-320. [CrossRef] [PubMed]

62. Muñoz-Ruiz, P.; Rubio, L.; García-Palomero, E.; Dorronsoro, I.; del Monte-Millán, M.; Valenzuela, R.; Usán, P.; de Austria, C.; Bartolini, M.; Andrisano, V.; et al. Design, synthesis, and biological evaluation of dual binding site acetylcholinesterase inhibitors: New disease-modifying agents for Alzheimer's disease. J. Med. Chem. 2005, 48, 7223-7233. [CrossRef] [PubMed]

63. Savelev, S.U.; Okello, E.; Perry, N.S.L.; Wilkins, R.M.; Perry, E.K. Synergistic and antagonistic interactions of anticholinesterase terpenoids in Salvia lavandulaefolia essential oil. Pharmacol. Biochem. Behav. 2003, 75, 661-668. [CrossRef]

64. Miyazawa, M.; Watanabe, H.; Umemoto, K.; Kameoka, H. Inhibition of acetylcholinesterase activity by essential oils of mentha species. J. Agric. Food Chem. 1998, 46, 3431-3434. [CrossRef]

65. Jukic, M.; Politeo, O.; Maksimovic, M.; Milos, M.; Milos, M. In vitro acetylcholinesterase inhibitory properties of thymol, carvacrol and their derivatives thymoquinone and thymohydroquinone. Phytother. Res. 2007, 21, 259-261. [CrossRef] [PubMed]

66. Dambolena, J.S.; Zunino, M.P.; Herrera, J.M.; Pizzolitto, R.P.; Areco, V.A.; Zygadlo, J.A. Terpenes: Natural products for controlling insects of importance to human health-A structure-activity relationship study. Psyche 2016, 2016, 4595823. [CrossRef]

67. López, M.D.; Pascual-Villalobos, M.J. Mode of inhibition of acetylcholinesterase by monoterpenoids and implications for pest control. Ind. Crop. Prod. 2010, 31, 284-288. [CrossRef]

68. Savelev, S.U.; Okello, E.J.; Perry, E.K. Butyryl- and acetyl-cholinesterase inhibitory activities in essential oils of Salvia species and their constituents. Phytother. Res. 2004, 18, 315-324. [CrossRef] [PubMed]

69. Sattelle, D.B. GABA receptors of insects. Adv. Insect Physiol. 1990, 22, 1-113.

70. Ben-Ari, Y.; Khalilov, I.; Kahle, K.T.; Cherubini, E. The GABA excitatory/inhibitory shift in brain maturation and neurological disorders. Neuroscientist 2012, 18, 467-486. [CrossRef] [PubMed]

71. Kandel, E.R. Principles of Neural Science, 5th ed.; Schwartz, J.H., Jessell, T.M., Siegelbaum, S., Hudspeth, A.J., Eds.; McGraw-Hill: New York, NY, USA, 2013.

72. Sigel, E.; Steinmann, M.E. Structure, function, and modulation of GABA $\mathrm{A}_{\mathrm{A}}$ receptors. J. Biol. Chem. 2012, 287, 40224-40231. [CrossRef] [PubMed]

73. Bloomquist, J.R. Chloride channels as tools for developing selective insecticides. Arch. Insect Biochem. Physiol. 2003, 54, 145-156. [CrossRef] [PubMed] 
74. Olsen, R.W.; Sieghart, W. GABA A receptors: Subtypes provide diversity of function and pharmacology. Neuropharmacology 2009, 56, 141-148. [CrossRef] [PubMed]

75. Priestley, C.M.; Williamson, E.M.; Wafford, K.A.; Sattelle, D.B. Thymol, a constituent of thyme essential oil, is a positive allosteric modulator of human $\mathrm{GABA}_{\mathrm{A}}$ receptors and a homo-oligomeric GABA receptor from Drosophila melanogaster. Br. J. Pharmacol. 2003, 140, 1363-1372. [CrossRef] [PubMed]

76. Hall, A.C.; Turcotte, C.M.; Betts, B.A.; Yeung, W.Y.; Agyeman, A.S.; Burk, L.A. Modulation of human GABA and glycine receptor currents by menthol and related monoterpenoids. Eur. J. Pharmacol. 2004, 506, 9-16. [CrossRef] [PubMed]

77. García, D.A.; Bujons, J.; Vale, C.; Suñol, C. Allosteric positive interaction of thymol with the GABA receptor in primary cultures of mouse cortical neurons. Neuropharmacology 2006, 50, 25-35. [CrossRef] [PubMed]

78. Watt, E.E.; Betts, B.A.; Kotey, F.O.; Humbert, D.J.; Griffith, T.N.; Kelly, E.W.; Veneskey, K.C.; Gill, N.; Rowan, K.C.; Jenkins, A.; et al. Menthol shares general anesthetic activity and sites of action on the GABA(A) receptor with the intravenous agent, propofol. Eur. J. Pharmacol. 2008, 590, 120-126. [CrossRef] [PubMed]

79. Hossain, S.J.; Aoshima, H.; Koda, H.; Kiso, Y. Fragrances in oolong tea that enhance the response of GABA receptors. Biosci. Biotechnol. Biochem. 2004, 68, 1842-1848. [CrossRef] [PubMed]

80. Ding, J.; Huang, C.; Peng, Z.; Xie, Y.; Deng, S.; Nie, Y.Z.; Xu, T.L.; Ge, W.H.; Li, W.G.; Li, F. Electrophysiological characterization of methyleugenol: A novel agonist of GABA(A) receptors. ACS Chem. Neurosci. 2014, 5, 803-811. [CrossRef] [PubMed]

81. Höld, K.M.; Sirisoma, N.S.; Ikeda, T.; Narahashi, T.; Casida, J.E. $\alpha$-Thujone (the active component of absinthe): $\gamma$-aminobutyric acid type A receptor modulation and metabolic detoxification. Proc. Natl. Acad. Sci. USA 2000, 97, 3826-3831.

82. Aoshima, H.; Hamamoto, K. Potentiation of $\mathrm{GABA}_{\mathrm{A}}$ receptors expressed in Xenopus oocytes by perfume and phytoncid. Biosci. Biotechnol. Biochem. 1999, 63, 743-748. [CrossRef] [PubMed]

83. Tong, F.; Coats, J.R. Effects of monoterpenoid insecticides on $\left[{ }^{3} \mathrm{H}\right]$-TBOB binding in house fly GABA receptor and ${ }^{36} \mathrm{Cl}^{-}$uptake in American cockroach ventral nerve cord. Pestic. Biochem. Physiol. 2010, 98, 317-324. [CrossRef]

84. Granger, R.E.; Campbell, E.L.; Johnston, G.A.R. (+)- And (-)-borneol: Efficacious positive modulators of GABA action at human recombinant $\alpha 1 \beta 2 \gamma 2$ L GABAA receptors. Biochem. Pharmacol. 2005, 69, 1101-1111. [CrossRef] [PubMed]

85. Hossain, S.J.; Hamamoto, K.; Aoshima, H.; Hara, Y. Effects of tea components on the response of GABA A receptors expressed in Xenopus oocytes. J. Agric. Food Chem. 2002, 50, 3954-3960. [CrossRef] [PubMed]

86. Bakkali, F.; Averbeck, S.; Averbeck, D.; Idaomar, M. Biological effects of essential oils-A review. Food Chem. Toxicol. 2008, 46, 446-475. [CrossRef] [PubMed]

87. Sánchez-Borzone, M.; Delgado-Marín, L.; García, D.A. Inhibitory effects of carvone isomers on the GABA receptor in primary cultures of rat cortical neurons. Chirality 2014, 26, 368-372. [CrossRef] [PubMed]

88. Yip, G.M.S.; Chen, Z.W.; Edge, C.J.; Smith, E.H.; Dickinson, R.; Hohenester, E.; Townsend, R.R.; Fuchs, K.; Sieghart, W.; Evers, A.S.; et al. A propofol binding site on mammalian GABA $_{A}$ receptors identified by photolabeling. Nat. Chem. Biol. 2013, 9, 715-720. [CrossRef] [PubMed]

89. Jayakar, S.S.; Zhou, X.; Chiara, D.C. Multiple propofol-binding sites in a $\gamma$-aminobutyric acid type A receptor $\left(\mathrm{GABA}_{\mathrm{A}} \mathrm{R}\right)$ identified using a photoreactive propofol analog. J. Biol. Chem. 2014, 289, 27456-27468. [CrossRef] [PubMed]

90. Olsen, R.W. Allosteric ligands and their binding sites define $\gamma$-aminobutyric acid (GABA) type A receptor subtypes. Adv. Pharmacol. 2015, 73, 167-202. [PubMed]

91. Ascari, J.; Sens, S.L.; Nunes, D.S.; Wisniewski, A., Jr.; Arbo, M.D.; Linck, V.M.; Lunardi, P.; Leal, M.B.; Elisabetsky, E. Sedative effects of essential oils obtained from Baccharis uncinella. Pharm. Biol. 2012, 50, 113-119. [CrossRef] [PubMed]

92. Silva, L.L.; Garlet, Q.I.; Benovit, S.C.; Dolci, G.; Mallmann, C.A.; Bürger, M.E.; Baldisserotto, B.; Longhi, S.J.; Heinzmann, B.M. Sedative and anesthetic activities of the essential oils of Hyptis mutabilis (Rich.) Briq. and their isolated components in silver catfish (Rhamdia quelen). Braz. J. Med. Biol. Res. 2013, 46, 771-779. [CrossRef] [PubMed]

93. Henderson, J.E.; Soderlund, D.M.; Knipple, D.C. Characterization of a putative $\gamma$-aminobutyric-acid (GABA) receptor $\beta$-subunit gene from Drosophila melanogaster. Biochem. Biophys. Res. Commun. 1993, 193, 474-482. [CrossRef] [PubMed] 
94. Aronstein, K.; Auld, V.; Ffrench-Constant, R. Distribution of two GABA receptor-like subunits in the Drosophila CNS. Invertebr. Neurosci. 1996, 2, 115-120. [CrossRef]

95. Dupuis, J.P.; Bazelot, M.; Barbara, G.S.; Paute, S.; Gauthier, M.; Raymond-Delpech, V. Homomeric RDL and heteromeric RDL/LCCH3 GABA receptors in the honeybee antennal lobes: Two candidates for inhibitory transmission in olfactory processing. J. Neurophysiol. 2010, 103, 458-468. [CrossRef] [PubMed]

96. McGonigle, I.; Lummis, S.C.R. Molecular characterization of agonists that bind to an insect GABA receptor. Biochemistry 2010, 49, 2897-2902. [CrossRef] [PubMed]

97. Ashby, J.A.; McGonigle, I.V.; Price, K.L.; Cohen, N.; Comitani, F.; Dougherty, D.A.; Molteni, C.; Lummis, S.C. GABA binding to an insect GABA receptor: A molecular dynamics and mutagenesis study. Biophys. J. 2012, 103, 2071-2081. [CrossRef] [PubMed]

98. Ffrench-Constant, R.H.; Mortlock, D.P.; Shaffer, C.D.; MacIntyre, R.J.; Roush, R.T. Molecular cloning and transformation of cyclodiene resistance in Drosophila: An invertebrate gamma-aminobutyric acid subtype A receptor locus. Proc. Natl. Acad. Sci. USA 1991, 88, 7209-7213. [CrossRef] [PubMed]

99. Belelli, D.; Callachan, H.; Hill-Venning, C.; Peters, J.A.; Lambert, J.J. Interaction of positive allosteric modulators with human and Drosophila recombinant GABA receptors expressed in Xenopus laevis oocytes. Br. J. Pharmacol. 1996, 118, 563-576. [CrossRef] [PubMed]

100. Hosie, A.M.; Aronstein, K.; Sattelle, D.B.; Ffrench-Constant, R.H. Molecular biology of insect neuronal GABA receptors. Trends Neurosci. 1997, 20, 578-583. [CrossRef]

101. Carvalho, K.S.; Silva, S.L.; de Souza, I.A.; Gualberto, S.A.; da Cruz, R.C.; Dos Santos, F.R.; de Carvalho, M.G. Toxicological evaluation of essential oil from the leaves of Croton tetradenius (Euphorbiaceae) on Aedes aegypti and Mus musculus. Parasitol. Res. 2016, 115, 3441-3448. [CrossRef] [PubMed]

102. Mehmood, F.; Khan, Z.U.; Manzoor, F.; Jamil, M. Analysis of Insect toxicity and repellent activity of Phytochemicals from "Skimmia laureola, Nair" against "Black garden ant, Lasius niger" of Pakistan. Pak. J. Pharm. Sci. 2016, 29, 789-793. [PubMed]

103. Turchen, L.M.; Piton, L.P.; Dall'Oglio, E.L.; Butnariu, A.R.; Pereira, M.J. Toxicity of Piper aduncum (Piperaceae) Essential Oil Against Euschistus heros (F.) (Hemiptera: Pentatomidae) and Non-Effect on Egg Parasitoids. Neotrop. Entomol. 2016, 45, 604-611. [CrossRef] [PubMed]

104. Waliwitiya, R.; Belton, P.; Nicholson, R.A.; Lowenberger, C.A. Effects of the essential oil constituent thymol and other neuroactive chemicals on flight motor activity and wing beat frequency in the blowfly Phaenicia sericata. Pest Manag. Sci. 2010, 66, 277-289. [CrossRef] [PubMed]

105. Nathanson, J.A. Octopamine receptors, adenosine $3^{\prime}, 5^{\prime}$-monophosphate, and neural control of firefly flashing. Science 1979, 203, 65-68. [CrossRef] [PubMed]

106. Orchard, I.; Carlisle, J.A.; Loughton, B.G.; Gole, J.W.; Downer, R.G. In vitro studies on the effects of octopamine on locust fat body. Gen. Comp. Endocrinol. 1982, 48, 7-13. [CrossRef]

107. Lange, A.B.; Orchard, I. Identified octopaminergic neurons modulate contractions of locust visceral muscle via adenosine $3^{\prime}, 5^{\prime}$-monophosphate (cyclic AMP). Brain Res. 1986, 363, 340-349. [CrossRef]

108. Perić-Mataruga, V.; Nenadovic, V.; Ivanovic, J. Neurohormones in insect stress: A review. Arch. Biol. Sci. 2006, 58, 1-12. [CrossRef]

109. Davenport, A.P.; Evans, P.D. Stress-induced changes in the octopamine levels of insect haemolymph. Insect Biochem. 1984, 14, 135-143. [CrossRef]

110. Kozanek, M.; Jurani, M.; Somogyiova, E. Influence of social stress on monoamine concentration in the central nervous system of the cockroach Nauphoeta cinerea (Blattodea). Acta Entomol. Bohemoslov. 1986, 83, 171-178.

111. Zhou, C.; Rao, Y.; Rao, Y. A subset of octopaminergic neurons are important for Drosophila aggression. Nat. Neurosci. 2008, 11, 1059-1067. [CrossRef] [PubMed]

112. Farooqui, T. Review of octopamine in insect nervous systems. Insect Physiol. 2012, 4, 1-17. [CrossRef]

113. Evans, P.D.; Maqueira, B. Insect octopamine receptors: A new classification scheme based on studies of cloned Drosophila G-protein coupled receptors. Invertebr. Neurosci. 2005, 5, 111-118. [CrossRef] [PubMed]

114. Wu, S.F.; Yao, Y.; Huang, J.; Ye, G.Y. Characterization of a $\beta$-adrenergic-like octopamine receptor from the rice stem borer (Chilo suppressalis). J. Exp. Biol. 2012, 215, 2646-2652. [CrossRef] [PubMed]

115. Cazzamali, G.; Klaerke, D.A.; Grimmelikhuijzen, C.J.P. A new family of insect tyramine receptors. Biochem. Biophys. Res. Commun. 2005, 338, 1189-1196. [CrossRef] [PubMed]

116. Bayliss, A.; Roselli, G.; Evans, P.D. A comparison of the signaling properties of two tyramine receptors from Drosophila. J. Neurochem. 2013, 125, 37-48. [CrossRef] [PubMed] 
117. Enan, E.E. Insecticidal activity of essenial oils: Octopaminergic sites of action. Comp. Biochem. Physiol. Part C Toxicol. Pharmacol. 2001, 130, 325-337. [CrossRef]

118. Pan, C.; Li, W.; Wang, Y.; Jiang, S. Octopamine levels in Blattella germanica L. tissues by capillary gas chromatography with electron capture detection. Int. J. Mol. Sci. 2005, 6, 188-197.

119. Kostyukovsky, M.; Rafaeli, A.; Gileadi, C.; Demchenko, N.; Shaaya, E. Activation of octopaminergic receptors by essential oil constituents isolated from aromatic plants: Possible mode of action against insect pests. Pest Manag. Sci. 2002, 58, 1101-1106. [CrossRef] [PubMed]

120. Enan, E.E. Molecular response of Drosophila melanogaster tyramine receptor cascade to plant essential oils. Insect Biochem. Mol. Biol. 2005, 35, 309-321. [CrossRef] [PubMed]

121. Grifman, M.; Arbel, A.; Ginzberg, D.; Glick, D.; Elgavish, S.; Shaanan, B.; Soreq, H. In vitro phosphorylation of acetylcholinesterase at non-consensus protein kinase A sites enhances the rate of acetylcholine hydrolysis. Brain Res. Mol. Brain Res. 1997, 51, 179-187. [CrossRef]

122. Kaufmann, D.; Dogra, A.K.; Wink, M. Myrtenal inhibits acetylcholinesterase, a known Alzheimer target. J. Pharm. Pharmacol. 2011, 63, 1368-1371. [CrossRef] [PubMed]

123. Fujiwara, M.; Yagi, N.; Miyazawa, M. Acetylcholinesterase inhibitory activity of volatile oil from Peltophorum dasyrachis Kurz ex Bakar (Yellow Batai) and bisabolane-type sesquiterpenoids. J. Agric. Food Chem. 2010, 58, 2824-2829. [CrossRef] [PubMed]

124. Dohi, S.; Terasaki, M.; Makino, M. Acetylcholinesterase inhibitory activity and chemical composition of commercial essential oils. J. Agric. Food Chem. 2009, 57, 4313-4318. [CrossRef] [PubMed]

125. Menichini, F.; Tundis, R.; Loizzo, M.R.; Bonesi, M.; Marrelli, M.; Statti, G.A.; Menichini, F.; Conforti, F. Acetylcholinesterase and butyrylcholinesterase inhibition of ethanolic extract and monoterpenes from Pimpinella anisoides V Brig. (Apiaceae). Fitoterapia 2009, 80, 297-300. [CrossRef] [PubMed]

126. Aazza, S.; Lyoussi, B.; Miguel, M.G. Antioxidant and antiacetylcholinesterase activities of some commercial essential oils and their major compounds. Molecules 2011, 16, 7672-7690. [CrossRef] [PubMed]

127. Bhadra, S.; Mukherjee, P.K.; Kumar, N.S.; Bandyopadhyay, A. Anticholinesterase activity of standardized extract of Illicium verum Hook. f. fruits. Fitoterapia 2011, 82, 342-346. [CrossRef] [PubMed]

128. Mata, A.T.; Proença, C.; Ferreira, A.R.; Serralheiro, M.L.M.; Nogueira, J.M.F.; Araújo, M.E.M. Antioxidant and antiacetylcholinesterase activities of five plants used as Portuguese food spices. Food Chem. 2007, 103, 778-786. [CrossRef]

129. Bonesi, M.; Menichini, F.; Tundis, R. Acetylcholinesterase and butyrylcholinesterase inhibitory activity of Pinus species essential oils and their constituents. J. Enzym. Inhib. Med. Chem. 2010, 25, 622-628. [CrossRef] [PubMed]

130. Arruda, M.; Viana, H.; Rainha, N.; Neng, N.R.; Rosa, J.S.; Nogueira, J.M.; Barreto Mdo, C. Anti-acetylcholinesterase and antioxidant activity of essential oils from Hedychium gardnerianum Sheppard ex Ker-Gawl. Molecules 2012, 17, 3082-3092. [CrossRef] [PubMed]

131. Perry, N.S.; Houghton, P.J.; Theobald, A.; Jenner, P.; Perry, E.K. In vitro inhibition of human erythrocyte acetylcholinesterase by Salvia lavandulaefolia essential oil and constituent terpenes. J. Pharm. Pharmacol. 2000, 52, 895-902. [CrossRef] [PubMed]

(C) 2017 by the authors. Licensee MDPI, Basel, Switzerland. This article is an open access article distributed under the terms and conditions of the Creative Commons Attribution (CC BY) license (http://creativecommons.org/licenses/by/4.0/). 